\title{
PRIKAZ UDOMITELJSTVA KAO OBLIKA SKRBI ZA OSOBE STARIJE ŽIVOTNE DOBI U HRVATSKOJ
}

\section{AN OVERVIEW OF FOSTER CARE AS A FORM OF CARE FOR OLDER PERSONS IN CROATIA}

\author{
ANA ŠTAMBUK ${ }^{1}$, MARIJA PENAVA ŠIMAC ${ }^{2}$ \\ ${ }^{1}$ Faculty of Law, University of Zagreb, Nazorova 51, Zagreb, Croatia, contact: astambuk@pravo.hr \\ ${ }^{2}$ Ministry of Labour, Pension System, Family and Social Policy, Ul. grada Vukovara 78, Zagreb, Croatia
}

Primljeno/ Received: 29.01.2021.

Prihvaćeno/ Accepted: 20.09.2021.

Sažetak: Udomiteljstvo se definira kao oblik pružanja socijalne usluge smještaja djetetu ili odrasloj osobi, koju pruža udomitelj sa svojom obitelji ili udomitelj koji živi sam, pod određenim uvjetima. U radu je prikazano udomiteljstvo za osobe starije životne dobi kroz teorijsku i istraživačku prizmu te udomiteljstvo u kontekstu procesa deinstitucionalizacije. Svrha je udomiteljstva osiguravanje skrbi i potpore korisniku u poticajnom i pozitivnom obiteljskom okruženju u skladu s njegovim individualnim planom promjene. Iako se posljednjih godina uočava porast broja osoba starije životne dobi smještenih u udomiteljske obitelji u Hrvatskoj, izostalo je zanimanje i kriticki osvrt znanstvene zajednice za ovaj oblik skrbi. Stoga je svrha rada opisati udomiteljstvo za osobe starije životne dobi u RH s ciljem unapređenja ovog oblika skrbi.

Ključne riječi: osobe starije životne dobi, udomiteljstvo, deinstitucionalizacija

\section{UVOD}

Organizacija skrbi za osobe starije životne dobi u europskim je zemljama različita te se može podijeliti na četiri tipa vezano uz geografski položaj. U zemljama južne Europe u kojima je zastupljen koncept tradicionalne obitelji briga i skrb za osobe starije životne dobi odvija se unutar obitelji, a mreža javnih institucija za skrb slabo je razvijena. U nordijskim zemljama zajednički život starijih osoba unutar obitelji praktično je nestao i u tim je zemljama razvijena javna skrb o osobama starije
Pregledni rad / Review article UDK: 364-54-053.9 doi: $10.31299 /$ hrri.57.2.8

\begin{abstract}
Foster care is a type of social service where accommodation is provided to children or adults under certain conditions by foster parents (including single parents), or foster care providers and their families. The paper provides an overview of foster care for older persons from a theoretical and research perspective, as well as foster care in the context of deinstitutionalisation. The purpose of foster care is to provide care and support to individuals in need by providing a stimulating and positive family environment in accordance with their individual plan of change. Despite a recent increase in the number of older persons placed in foster families in Croatia, there is a lack of interest in the scientific community to critically assess this type of care. Therefore, the purpose of this paper is to highlight the importance of foster care for older persons in Croatia with the aim of improving this form of care.
\end{abstract}

Keywords: older persons, foster care, deinstitutionalisation

\section{INTRODUCTION}

The process by which care for older persons is organised across European countries can be categorised into four approaches based on geographical location. In southern European countries where the concept of the traditional family prevails, care for older persons is provided by the family, and the network of public care institutions is poorly developed. In the Nordic countries, very few individuals continue to cohabitate with older members of their family. Therefore, public care for older persons is well 
životne dobi. Zbog toga postoji široka i dostupna mreža javnih institucija koje pružaju besplatne ili relativno jeftine usluge starijim osobama. U anglosaksonskim zemljama, Ujedinjenom Kraljevstvu i Irskoj, slabo je zastupljen model skrbi za osobe starije životne dobi unutar obitelji, a razvijeno je i po cijenama dostupno privatno tržište usluga za starije. S druge strane u zemljama srednje Europe skrb je temeljena na dodatnom socijalnom osiguranju na osnovi uplata posebnih doprinosa (Puljiz, 2016). Iz svega navedenog može se zaključiti da skrb za starije prelazi na državu u onim zemljama gdje istu nije moguće ostvariti unutar obitelji. Naime kako koncept tradicionalne obitelji slabi, dio skrbi za osobe starije životne dobi preuzimaju institucije (Jedvaj, Štambuk i Rusac, 2014).

Razvoj javne skrbi za osobe starije životne dobi u sustavu socijalne skrbi u Hrvatskoj počinje sredinom 20. stoljeća i to usmjeravanjem isključivo na razvoj institucionalnih usluga kroz osnivanje domova. Izvaninstitucijske usluge za osobe starije životne dobi počinju se razvijati 60-ih godina prošlog stoljeća, prvim Zakonom o socijalnoj zaštiti (NN 19/69). Udomiteljska skrb za osobe starije životne dobi razvija se početkom 1970. godine kao smještaj odraslih osoba u druge obitelji (Dobrotić, 2016). Ovaj oblik skrbi za osobe starije životne dobi bio je poprilično nerazvijen u 80 -im godinama prošlog stoljeća. Međutim u 90 -ima se počinje zagovarati udomiteljska skrb za osobe starije životne dobi kao poželjan oblik skrbi zbog prisutnog deficita smještajnih kapaciteta u domovima socijalne skrbi (ك̌kara, 1999). Naime svega 2\% starije populacije u Hrvatskoj smješteno je u domove za starije, iako se u mnogim zemljama Europe taj broj kreće oko 5\% populacije, dok su usluge izvaninstitucionalne skrbi slabo razvijene (Žganec, Rusac, Laklija, 2008). Istovremeno u Hrvatskoj započinje i proces deinstitucionalizacije s ciljem promjene u omjeru između institucijske i izvaninstitucijske skrbi u korist izvaninstitucije (Plan deinstitucionalizacije, transformacije te prevencije institucionalizacije 2018.-2020., 2018).

Prema Zakonu o socijalnoj skrbi (NN 157/13, 152/14, 99/15, 52,16, 16/17, 13/17, 98/19) osoba starije životne dobi može ostvariti pravo na naknade i pravo na usluge ukoliko udovoljava uvjetima propisanim zakonom. Starije osobe koje se nalaze developed in these countries: there is a broad and accessible network of public institutions that provide free or relatively inexpensive services to older individuals in need. In Anglo-Saxon countries, including the United Kingdom and Ireland, the model of care for older individuals within the family is poorly represented, therefore, there is a market for affordable private services for older pesons. In contrast, central European countries base their care services on additional social insurance financed through special contributions (Puljiz, 2016). Nevertheless, in all four cases, when family care is unavailable, the state takes over the care of older individuals. In the last decades, the concept of the traditional family has weakened, leading to the development of institutions that can assume part of the responsibility of providing care to older individuals (Jedvaj, Štambuk \& Rusac, 2014).

In Croatia, the development of public care for older persons within the social welfare system began in the mid-twentieth century: the aim was to expand institutional services by establishing retirement homes. In the 1960s, the first Social Welfare Act (Official Gazette No. 19/69) introduced noninstitutional services for older persons, and the beginning of the 1970s saw the provision of foster care for older individuals in the form of adult placements in foster families (Dobrotić, 2016). This form of care did not undergo any significant developments in the 1980s. However, in the 1990s, social welfare institutions strongly advocated for foster care for older persons due to capacity constraints in social welfare homes (Škara, 1999). Only $2 \%$ of the population of older individuals in Croatia can be placed in retirement homes, while in many other European countries, this figure can reach $5 \%$ since the scope of noninstitutional care services are poorly developed (Žganec, Rusac, Laklija, 2008). At the same time, Croatia launched the deinstitutionalisation process aimed to redistribute institutional and noninstitutional care services, as well as favour the development of noninstitutional types of care (Plan for deinstitutionalisation, transformation and prevention of institutionalisation 2018-2020, 2018).

Based on the Social Welfare Act (Official Gazette 157/13, 152/14, 99/15, 52,16, 16/17, 13/17, 98/19), older persons are entitled to certain benefits and services if they meet the requirements outlined in the legislation. Older individuals who have faced/continue to face adverse life circumstances and lack the 
u teškoj životnoj situaciji i nemaju dostatna sredstva za zadovoljavanje osnovnih životnih potreba u sustavu socijalne skrbi najčešće koriste sljedeća prava propisana navedenim zakonom: zajamčena minimalna naknada, doplatak za pomoć i njegu, osobnu invalidninu, uslugu pomoći u kući i uslugu smještaja. Dužina trajanja usluge smještaja može biti privremena ili dugotrajna, a može trajati sve dane $u$ tjednu ili tijekom pet radnih dana. Uslugu smještaja pružaju: dom socijalne skrbi, centar za pružanje usluga u zajednici, drugi pružatelji usluga (udruga, vjerska zajednica, trgovačko društvo, domaća i strana pravna osoba te obrtnik) ili fizička osoba (udomitelj ili obiteljski dom).

\section{RAZVOJ UDOMITELJSTVA ZA OSOBE STARIJE ŽIVOTNE DOBI U REPUBLICI HRVATSKOJ}

Udomiteljstvo se prvi put spominje u Zakonu o prisilnom odgoju nedoraslih iz 1902. godine, a dvadeset godina kasnije, 1922. godine, kada je donesen Zakon o zaštiti djece i mladeži, preporučuje se smještaj djece u obitelj. Na području Republike Hrvatske 1937. godine osnivaju se državne dječje kolonije u Mraclinu i Krapini. Tako se na području Velike Gorice i do danas održala tradicija udomljavanja djece (Gašparec, 1991). Krajem 80-ih i početkom 90-ih godina u Hrvatskoj stručna i znanstvena zajednica prepoznala je potencijale $i$ prednosti udomiteljskog smještaja korisnika te se organizira prvi tečaj iz područja socijalnog rada na temu ,Specijalizirani smještaj u drugu obitelj kao alternativa institucionalnom smještaju“ pri Interuniverzitetskom centru za poslijediplomske studije u Dubrovniku (Selak-Živković, 1991).

Udomiteljstvo je oblik izvaninstitucijske usluge smještaja kojom se osigurava skrb i potpora korisniku u poticajnom i pozitivnom obiteljskom okruženju. Donošenje Zakona o udomiteljstvu 2007. godine (NN, 79/07) predstavlja značajnu prekretnicu u razvoju udomiteljstva koje je do tada bilo regulirano u okviru Zakona o socijalnoj skrbi. U cilju kvalitetnijeg pristupa udomiteljstvu navedenim su Zakonom na jedinstven način propisane obveze udomitelja i centara za socijalnu skrb, ustrojeni su timovi za udomiteljstvo u centrima za socijalnu skrb, osigurana je osobna naknada udomiteljima za uloženi trud u svakodnevnoj skrbi za means to meet their basic needs can exercise the following rights under the Social Welfare Act: guaranteed minimum benefits, allowance for assistance and care, personal disability allowance, as well as home assistance and accommodation services. The duration of accommodation services may vary from temporary to long-term, extending over the entire week or only for the five working days. These accommodation services can be provided by social welfare homes, community service centres, other service providers (associations, religious communities, companies, sole proprietorship businesses, domestic and foreign legal entities), as well as foster care providers or families.

\section{DEVELOPMENT OF FOSTER CARE FOR OLDER PERSONS IN CROATIA}

Foster care was first mentioned in the Mandatory Juvenile Upbringing Act of 1902. Twenty years later, the Child and Youth Protection Act of 1922 recommended the placement of children in foster families. In 1937, state colonies for foster children were established in Mraclin and Krapina within the territory of the Republic of Croatia. One example is the region of Velika Gorica, which has continued to maintain the tradition of foster care for children for many decades (Gašparec, 1991). In the late 1980s and early 1990s, the professional and scientific community in Croatia recognised the potential and advantages of foster care placement for individuals in need. This led to the first scientific course in social work titled "Specialised Accommodation in Other Families as an Alternative to Institutional Accommodation", which was organised at the Inter-University Centre for Postgraduate Studies in Dubrovnik (Selak-Živković, 1991).

Foster care is a form of noninstitutional accommodation service that provides care and support to the user in a stimulating and positive family environment. The adoption of the Foster Care Act in 2007 (Official Gazette, 79/07) represents a significant milestone in the development of foster care, which until then had been regulated through the Social Welfare Act. In order to improve access to foster care, the aforementioned Act stipulates the obligations of foster parents and care providers, as well as of social welfare centres, in a unique way: foster care teams were formed in social welfare centres, personal compensation was provided to foster care providers for the daily care that they provided to the 
korisnika, smanjen je broj korisnika u jednoj udomiteljskoj obitelji te je na jedinstven način regulirano uvođenje evidencije i registra udomiteljskih obitelji i smještenih korisnika.

Pozitivni pomaci u području udomiteljstva nastavljeni su u okviru daljnjih reformi sustava socijalne skrbi. Strategijom razvoja sustava socijalne skrbi u Republici Hrvatskoj 2011.-2016. jedan od prioriteta razvoja sustava socijalne skrbi bio je unapređenje udomiteljske skrbi u Republici Hrvatskoj. Tada je utvrđeno da je udomiteljstvo kao oblik skrbi za neke kategorije korisnika nerazvijeno te je jedna od planiranih mjera bila poticanje razvoja udomiteljstva za skupine korisnika sa specifičnim potrebama. Nadalje s obzirom na veliku regionalnu nejednakost u pogledu rasprostranjenosti udomiteljstva definirana je mjera koja se odnosila na poticanje ravnomjernog razvoja udomiteljstva na području cijele Republike Hrvatske. Također s obzirom na značajnu ulogu udomitelja u životu smještene osobe čije potrebe su sve složenije bilo je predviđeno da se osigura potpora udomiteljskim obiteljima putem centara za socijalnu skrb i domova socijalne skrbi s time da će se u provedbu edukacije, supervizije i potpore udomiteljskim obiteljima, u okviru procesa transformacije, uključiti i domovi socijalne skrbi.

U kontekstu planiranih promjena u srpnju 2011. godine donesen je novi Zakon o udomiteljstvu kojim je, između ostalih novina, uvedeno profesionalno udomiteljstvo za neke skupine djece i mlađih punoljetnih osoba te za osobe s težim invaliditetom. Zakonom o izmjenama i dopunama Zakona o udomiteljstvu iz srpnja 2012. (NN, 78/12) izbrisane su odredbe koje se odnose na profesionalizaciju udomiteljstva čime profesionalizacija udomiteljstva nije uvedena. Time je na neki način udomiteljstvo stavljeno na margine, odnosno i udomitelji i korisnici ,prepušteni su sami sebi“.

Jedan od posebnih ciljeva u okviru prioriteta za provedbu procesa deinstitucionalizacije i transformacije te prevencije institucionalizacije za odrasle osobe s invaliditetom jest razvijanje izvaninstitucijskih socijalnih usluga za korisnike koji ne mogu ostati u vlastitoj obitelji, a nije im potrebna dugotrajna intenzivna skrb (udomiteljstvo, obiteljski domovi i dr.). individual in need, the number of users in one foster family was reduced, and the introduction of records and registers of foster families and individuals who required foster case was clearly regulated. Positive developments in the field of foster care have continued as part of further reforms of the social welfare system. The Strategy of Social Welfare Development in the Republic of Croatia (2011-2016) emphasises that one of the priorities for the development of the social welfare system was the improvement of foster care in the Republic of Croatia. It was then established that foster care was underdeveloped as a form of care, and one of the planned measures was to promote the development of foster care for groups of individuals with specific needs. Furthermore, given the large regional disparity in terms of the prevalence of foster care, a measure was defined that referred to promoting the balanced development of foster care throughout the Republic of Croatia. Also, given the significant role of foster care providers in the life of a individual who requires a foster family, whose needs are becoming more complex, it was envisaged to provide support to foster families through social welfare centres and homes, whereby training, supervision, and provision of support to foster families can be implemented within the transformation process.

In the context of the planned changes, a new Foster Care Act was adopted in July 2011, which, among other novelties, introduced professional foster care for certain groups of children and young adults, as well as for people with severe disabilities. The Act Amending the Foster Care Act of July 2012 (Official Gazette, 78/12) deleted the provisions relating to the professionalisation of foster care, which did not introduce the professionalisation of foster care. In this way, foster care is marginalised, i.e. both foster care providers and users are "left to fend for themselves".

One of the special goals within the priorities for the implementation of the process of deinstitutionalisation, transformation, and prevention of institutionalisation of adults with disabilities is the development of noninstitutional social services for individuals who cannot live in their own family, but do not need longterm intensive care (foster care, family homes).

Furthermore, despite efforts to improve foster care for all those who require it, there continue to be difficulties in the field of foster care such as different levels of quality of foster care, unequal regional prevalence 
Nadalje unatoč nastojanjima da se unaprijedi udomiteljska skrb za sve korisnike i dalje su bile prisutne poteškoće u području udomiteljstva poput različite razine kvalitete udomiteljske skrbi o korisnicima, nejednake regionalne rasprostranjenosti udomiteljstva, nepovoljne dobne i obrazovne strukture udomitelja, slabog odaziva novih obitelji za bavljenje udomiteljstvom posebice obitelji mlađe životne dobi i višeg stupnja obrazovanja. U prosincu 2018. godine donesen je novi Zakon o udomiteljstvu (NN,115/18) kojim je omogućeno obavljanje udomiteljstva kao zanimanja koje se obavlja kao standardno udomiteljstvo i specijalizirano udomiteljstvo za djecu, a udomiteljima koji obavljaju udomiteljstvo kao zanimanje omogućuje se pravo na opskrbninu, naknadu za rad udomitelja, prava iz mirovinskog i obveznog zdravstvenog osiguranja i prava za vrijeme nezaposlenosti. Trošak smještaja jednog korisnika u udomiteljskoj obitelji kreće se od 2.400 do 3.500 kn što ovisi o broju i vrsti korisnika te tipu udomiteljstva. Maksimalan je broj korisnika smještenih u jednu obitelj četiri.

Udomiteljska obitelj mora ispunjavati zakonom propisane stambene, socijalne i druge uvjete (Zakon o udomiteljstvu, NN,115/18). Uvjete ocjenjuje centar za socijalnu skrb koji je prema mjestu prebivališta udomiteljske obitelji za nju nadležan, a u obradi obitelji sudjeluje stručni tim koji čine: socijalni radnik, psiholog, pravnik i liječnik, a po potrebi i drugi odgovarajući stručnjaci. Korisnici se smještaju u udomiteljske obitelji temeljem rješenja centra za socijalnu skrb. Udomitelj mora biti psihički i tjelesno zdrav, sposoban čuvati, štititi te zadovoljiti potrebe smještenog djeteta. Udomiteljska obitelj ne može biti obitelj u kojoj je udomitelju ili drugom članu obitelji oduzeto pravo na roditeljsku skrb, u kojoj su poremećeni obiteljski odnosi, u kojoj je udomitelj ili član obitelji osoba društveno neprihvatljivog ponašanja, u kojoj bi zbog mentalnog oštećenja ili bolesti udomitelja ili kojeg člana obitelji bilo ugroženo zdravlje ili drugi interesi korisnika. Nadzor nad radom udomitelja obavlja centar za socijalnu skrb na temelju javnih ovlasti te inspekcijska služba ministarstva nadležnog za poslove socijalne skrbi. Udomitelji su dužni pohađati edukacije.

Udomiteljstvo za osobe starije životne dobi zadnjih je godina sve više prisutno u Republici of foster care, unfavourable foster care provider demographics pertaining to age and educational attainment, as well as low response of new families to foster care, especially of younger families whose members have higher educational attainment. In December 2018, the new Foster Care Act was adopted (Official Gazette, $115 / 18$ ), which made it possible to engage in foster care as an occupation performed as standard and specialised foster care for children. Foster parents engaged in foster care provision as an occupation are provided with the right to living costs allowance, foster care provision compensation, pension, and mandatory health insurance and unemployment rights. The cost of accommodating one new person in a foster family can range from HRK 2,400 to 3,500, depending on the number and type of individuals joining a foster family, as well as the type of foster care required. The maximum number of individuals who can be accommodated in one family is four.

The foster family must meet housing, social, and other conditions prescribed by law (Foster Care Act, Official Gazette, 115/18). The conditions are assessed by the social welfare centre that is vested with this responsibility in relation to the foster family based on the place of residence of the foster family. An expert team consisting of a social worker, a psychologist, a lawyer, and a physician participates in family assessment, as well as other experts of appropriate professions if necessary. Individuals are placed in foster families based on the decision adopted by the social welfare centre. The foster care provider must be mentally and physically healthy, and demonstrate their ability to care for, protect, and meet the needs of the accommodated child. In the following situations, a family is not allowed to become a foster family: 1) where a foster parent or other family members has been deprived of the right to parental care, 2) where existing family relationships are dysfunctional, 3) where a foster parent or family member is a person behaving in a socially unacceptable manner, and 4) where history of mental impairment or illness in the foster parent or a family member can jeopardise the health or other interests of the individual who requires a foster family. Supervision of the foster parents is performed by the social welfare centre on the basis of public powers, and the inspection department of the ministry is responsible for social welfare. Foster care providers are also required to attend regular training sessions. 
Ana Štambuk, Marija Penava Šimac: Prikaz udomiteljstva kao oblika skrbi za osobe starije životne dobi u Hrvatskoj / An overview of...

Tablica 1. Prikaz broja smještenih odraslih osoba udomiteljskih obitelji / Table 1. Presentation of the number of adults placed in foster families

\begin{tabular}{|l|c|c|c|c|c|}
\hline & $\mathbf{2 0 1 5}$ & $\mathbf{2 0 1 6}$ & $\mathbf{2 0 1 7}$ & $\mathbf{2 0 1 8}$ & $\mathbf{2 0 1 9}$ \\
\hline $\begin{array}{l}\text { Number of adults and older } \\
\text { individuals in foster families }\end{array}$ & 4323 & 4459 & 4412 & 4523 & 4693 \\
\hline Number of foster families & 1581 & 1557 & 1528 & 1454 & 1476 \\
\hline
\end{tabular}

Source: Annual statistical reports, MLFSP

Hrvatskoj (Tablica 1). No ako pogledamo tablicu možemo vidjeti da se broj smještenih odraslih osoba u udomiteljskim obiteljima povećava, a da se broj njihovih udomitelja smanjuje, što svakako predstavlja podatak koji treba istražiti.

\section{UDOMITELJSTVO I DEINSTITUCIONALIZACIJA}

Udomiteljstvo se kao oblik skrbi nametnulo kao jedna od alternativa institucionalnom obliku skrbi u procesu deinstitucionalizacije (Šućur, 2003). Procesi deinstitucionalizacije i transformacije podrazumijevaju redefiniranje funkcija domova socijalne skrbi, razvijajući alternativne usluge u zajednici kao npr. udomiteljstvo, obiteljske domove i jedinice za podršku samostalnom životu pojedinaca - koje se obavljaju što bliže onima koji ih zapravo trebaju (Teodorović i Miščević, 2014). Proces deinstitucionalizacije predstavlja praksu pružanja individualizirane, pojedincu prilagođene podrške u prirodnom okruženju (Ćirić Milovanović, 2017) što ne znači premještanje korisnika iz velikih rezidencijalnih ustanova u smještajne jedinice manjeg kapaciteta. Ona se treba sagledavati kao kompleksan proces koji podrazumijeva promjenu pristupa u pružanju podrške osobama uključujući prevenciju i širenje usluga u zajednici kako bi se smanjila potreba za institucionalnom zaštitom.

U Republici Hrvatskoj proces deinstitucionalizacije navodi se kao jedan od reformskih procesa i to u strateškom dokumentu vezanom za razvoj sustava socijalne skrbi iz 2003. U tom je dokumentu između ostalog navedeno da su udomiteljske obitelji oblik skrbi unutar navedenog koncepta (Strategija razvitka Republike Hrvatske $» H r v a t s k a$ u 21. stoljeću« - strategija razvitka mirovinskog sustava i sustava socijalne skrbi I. dio Hrvatska: od pasivne prema aktivnoj socijalnoj državi, 2003). Međutim, službeni početak procesa transformacije i deinstitucionalizacije kreće donošenjem Plana
Foster care for older individuals has been increasingly practised in the Republic of Croatia in the recent years (Table 1). However, we see that although the number of adults placed in foster families is increasing, the number of foster care providers is decreasing. This requires further investigation.

\section{FOSTER CARE AND DEINSTITUTIONALISATION}

In the context of deinstitutionalisation, foster care offers an alternative to institutional forms of care (Šućur, 2003). The processes of deinstitutionalisation and transformation involves a redefinition of the functions of social welfare homes through further development of alternative community-based services, such as foster care, family homes, and units for services supporting independent living, that are offered in the proximity of the individuals who need them (Teodorović \& Miščević, 2014). The deinstitutionalisation process denotes individualised, tailored support provision in the habitual environment (Ćirić Milovanović, 2017), rather than mere transfer of individuals from large residential institutions to smaller accommodation units. It should be seen as a complex process entailing a transformation of the approach to service provision, including prevention and the expansion of community-based services that reduce the need for institutional care.

As outlined in 2003 in the strategic document related to developing the social welfare system, the process of deinstitutionalisation has been considered one of the notable reform processes in Croatia. The document states, inter alia, that foster families represent a form of care within this concept (Strategy for the Development of the Republic of Croatia "Croatia in the $21^{\text {st }}$ Century" - strategy for the development of the pension system and social welfare system, part I, Croatia: from a passive to an active welfare state, 2003). Nonetheless, the adoption of the Plan for Deinstitutionalisation and Transformation of Social 
deinstitucionalizacije i transformacije domova socijalne skrbi i drugih pravnih osoba u Republici Hrvatskoj 2011.-2016. (NN, broj: 36/11). U navedenom dokumentu starije osobe kao korisnička skupina nisu bile $\mathrm{u}$ fokusu. Međutim promjene su vidljive u sljedećem Planu deinstitucionalizacije, transformacije te prevencije institucionalizacije 2018. -2020. (2018) jer je više pozornosti posvećeno skrbi za starije osobe. U navedenom Planu iz 2018. navodi se da organizacija skrbi za starije osobe predstavlja izazov za nosioce politike pri čemu se kao problem navodi nedostupnost usluga za starije osobe i nedostatno razvijene usluge $u$ zajednici, posebice usluge pomoći u kući i usluge dnevnog boravka. Također je navedeno da se radi o uslugama jeftinijim od institucijskih oblika skrbi, ali i djelotvornijim, jer preveniraju institucionalizaciju i pridonose socijalnoj uključenosti starijih osoba, kao i većoj kvaliteti njihova života uopće.

U strateškom dokumentu za razvoj sustava socijalne skrbi donesenom 2011. godine bila je vidljiva intencija unapređivanja izvaninstitucijskih oblika skrbi i prevencije institucionalizacije te se udomiteljstvo predlaže kao tradicionalni oblik skrbi (Strategija razvoja sustava socijalne skrbi 20112016). Nadalje u strateškim planovima ministarstva nadležnog za socijalnu skrb kada je u pitanju skrb o osobama starije životne dobi promiče se razvoj izvaninstitucijskih oblika skrbi te zadržavanje osoba starije životne dobi u krugu obitelji (Strateški plan Ministarstva socijalne politike i mladih za razdoblje od 2012. do 2014). Na razvijanje ovakvog koncepta skrbi za osobe starije životne dobi utjecao je i ulazak Republike Hrvatske u Europsku Uniju te preuzimanje Zajedničkih europskih smjernica za prijelaz $\mathrm{s}$ institucionalne skrbi na alternativne oblike skrbi i podrške u obitelji i zajednici za djecu, osobe s invaliditetom, osobe sa psihosocijalnim poteškoćama i starije osobe u Europi čime se intenzivnije počeo poticati proces deinstitucionalizacije na državnoj razini (Teodorović i Miščević, 2014). U Planu deinstitucionalizacije, transformacije te prevencije institucionalizacije iz 2018. godine deinstitucionalizacija je opisana kao dugotrajan i složen proces koji podrazumijeva da se osiguraju sve pretpostavke potrebne za uključivanje osoba u život lokalne zajednice (razvoj usluga u zajednici, dostupnost zdravstvenih usluga i usluga školova-
Welfare Institutions and other Legal Entities in the Republic of Croatia 2011-2016 (Official Gazette, No. $36 / 11$ ) officially marked the beginning of the process of transformation and deinstitutionalisation. However, the aforementioned document did not focus on the placement of older individuals. However, this changed in the following Plan of Deinstitutionalisation, Transformation, and Prevention of Institutionalisation 2018-2020 (2018) because more attention was paid to care for older individuals. The Plan (2018) acknowledged that setting up care services for older individuals represents a challenge for policymakers, citing the unavailability of services for older individuals and deficiency in community-based services as issues, including household assistance and day care services. It is also stated that these services are more affordable and efficient than institutional forms of care since they contribute to the prevention of institutionalisation, social inclusion, and an improved quality of life for older persons.

The strategic document for developing the social welfare system from 2011 conveyed an intention to advance noninstitutional forms of care and prevent institutionalisation by promoting foster care as a traditional form of care (Strategy for the Development of the Social Welfare System 2011-2016). Furthermore, concerning care for older persons, the strategic plans of the ministry in charge of social welfare promote the development of noninstitutional forms of care, such as keeping older individuals in the family circle (Strategic Plan of the Ministry of Social Policy and Youth for the period 2012-2014). Furthermore, Croatia's entry into the European Union and the adoption of the Common European Guidelines on the transition from institutional care to alternative community- and family-based forms of care and support for children, individuals with disabilities, those with psychosocial difficulties, and older individuals in Europe prompted the development of such a concept of care for older persons, spurring the process of deinstitutionalisation at the state level.

Directed at improving the position of senior citizens, a study from Bosnia and Herzegovina advocated for the implementation of the deinstitutionalisation process, especially concerning the issue of enhancing social inclusion of older individuals, against the backdrop of considerable costs of institutional care; this was important since 
nja, mogućnost zapošljavanja, promjena stavova stručne i opće javnosti, međusobna suradnja državnih tijela, tijela jedinica lokalne i područne (regionalne) samouprave, stručnih i znanstvenih institucija, organizacija civilnog društva $i \mathrm{dr}$.).

Istraživanje na području Bosne i Hercegovine s ciljem unapređenja stanja osoba treće životne dobi ističe preporuku provedbe procesa deinstitucionalizacije posebice kada je u pitanju unapređenje socijalne uključenosti starijih osoba u društvo pri čemu se navodi da je institucionalizacija izuzetno skupa i nije uvijek najbolje rješenje i u najboljem interesu svake starije osobe koja nije u mogućnosti brinuti se za sebe. Također se navodi da deinstitucionalizacija i pružanje različitih usluga koje su financijski povoljnije od bolničkog, odnosno domskog smještaja predstavljaju moguća rješenja koja su u većini slučajeva istovremeno i u najboljem interesu starije populacije (Kepeš, Huzejrović i Kujundžić, 2019). Slovenija je u kontekstu skrbi za starije osobe dosta oslonjena na koncept deinstitucionalizacije (Lenko, 2016) koji počiva na načelu prava na samostalan i neovisan život u starosti pri čemu skrb mora kombinirati dostupnost usluga podrške, visoku razinu kvalitete i financijsku održivost. Deinstitucionalizacija skrbi omogućava starijim osobama da slobodno odluče gdje će dobivati potrebnu pomoć i podršku, kod kuće ili u instituciji, odnosno predstavlja promjenu pogleda na starenje i starije osobe. Lenko (2016) navodi da podržavajući koncept deinstitucionalizacije ne znači da neće biti potreba za institucijom koja će i dalje imati važnu ulogu onda kada potrebe starijih osoba neće moći biti zadovoljene u kućnom okruženju.

U preporukama Europskog ekonomskog i socijalnog odbora 2015. između ostalog stoji kako visokokvalitetna skrb u lokalnoj zajednici daje bolje rezultate u pogledu kvalitete života od institucionalne skrbi što omogućava socijalnu uključenost i smanjuje rizik od isključenosti pri čemu se državama članicama preporučuje da reformiraju dugoročnu skrb na temelju analize troškova i učinkovitosti, istovremeno usvajajući dugoročni pristup i ulažući u ljude i usluge, umjesto da smanjuju sredstva (Lenko, 2016).

Mali (2012) navodi da ideje o deinstitucionalizaciji u području skrbi za starije osobe potječu institutional care is not the best solution at all times and does not always represent the best interest of older individuals who were no longer able to look after themselves (Kepeš, Huzejrović, \& Kujundžić, 2019). The study also suggested possible solutions under the umbrella of deinstitutionalisation, including more affordable services compared to accommodation in hospitals or retirement homes, which represented the best interest of most senior citizens (Kepeš, Huzejrović, \& Kujundžić, 2019). In terms of care for the edlerly, Slovenia has been consistently following the concept of deinstitutionalisation (Lenko, 2016) based on the right to a self-sufficient and independent life even at an old age, with care provision leveraging the availability, high quality, and financial sustainability of support services. The deinstitutionalisation of care allowed senior citizens to freely decide where they would like to receive the necessary assistance and support - at home or in an institution - and, therefore, changed the perception of ageing and older persons. Lenko (2016) confirmed that promoting the concept of deinstitutionalisation does not exclude the need for institutions, which would continue performing an important role when it was no longer possible to meet the needs of older individuals at home.

The recommendations of the European Economic and Social Committee in 2015 state, inter alia, that high-quality care in the local community can yield better results than institutional care in terms of quality of life, which allows for social inclusion and reduces the risk of exclusion. For this reason, Member States were urged to reform long-term care based on a cost-benefit analysis, and simultaneously adopt a long-term approach and investing in people and services, instead of reducing funding (Lenko, 2016).

Mali (2012) maintained that the ideas concerning deinstitutionalisation in the field of care for older individuals stemmed from the scientific and academic community. The author suggested that deinstitutionalisation entailed transforming the social welfare system in its operation at micro, macro, and mezzo levels, rather than making mere organisational changes. At the micro level, it involved influencing the consciousness of older individuals concerning their right to live in the 
iz znanstvenih i akademskih krugova. Autorica navodi da deinstitucionalizacija ne znači samo organizacijske promjene, već utječe i na promjene $\mathrm{u}$ funkcioniranju sustava socijalne skrbi na mikrorazini, makrorazini i mezorazini. Na mikrorazini utječe na svijest osoba starije životne dobi da imaju pravo na život u zajednici s drugim ljudima, da su uključeni u društveni život te da mogu sami odlučiti o svojoj sudbini, čak i kada su nemoćni i bolesni. Na mezorazini deinstitucionalizacija stvara potrebu za razvojem usluga koje će biti prilagođene potrebama osoba starije životne dobi kao alternative institucionalnoj skrbi. Autorica navodi da je za proces deinstitucionalizacije iznimno važno zakonodavstvo koji će na makrorazini omogućiti da se proces provede. Teodorović i Miščević (2014) navode da su nalazi ad hoc radne skupine pokazali da su korisnici na smještaju u instituciji izolirani od šire zajednice te da su prisiljeni živjeti zajedno, da nemaju dovoljnu kontrolu nad svojim životima $i$ odlukama koje utječu na njihov život te da zahtjevi institucije često imaju prioritet nad individualnim potrebama korisnika usluga. Također i socijalni radnici zaposleni u domovima za starije ističu problem zapostavljenosti individualnog rada s korisnicima, naglašenu administraciju u radu, potrebu za specifičnim edukacijama iz područja palijativne skrbi i rada s osobama sa psihoorganskim oboljenjima (Štambuk, Sučić i Vrh , 2014).

Promatrajući udomiteljstvo kao oblik skrbi u kontekstu deinstitucionalizacije potrebno bi bilo utvrditi ima li korisnik smješten u udomiteljsku obitelj kontrolu nad vlastitim životom, koristi li resurse zajednice u kojoj živi ili je izoliran od nje, radi li se o individualiziranom pristupu pružanja usluga ili ne (npr. raspored i kvaliteta obroka kod osoba koje boluju od dijabetesa ili drugih bolesti koje zahtijevaju specifičnu vrstu prehrane, obavljanje higijene i sl.).

Komparirajući uslugu smještaja u institucijskom obliku ili u izvaninstitucionalnom obliku tj. udomiteljstvu može se reći da se radi o sadržajno istoj usluzi. To znači da korisniku koji je smješten u udomiteljsku obitelji moraju biti zadovoljene potrebe kao i u institucijskoj skrbi. Razlika između ova dva oblika skrbi vidljiva je u načinu na koji se skrb pruža u odnosu na prostor, opremu, broj stručnih i drugih radnika te u organizacijskom obliku. community with other people, inclusion in social life, and the ability to decide for themselves, even if they were sick or infirm. At the mezzo level, the deinstitutionalisation urged further development of services tailored to the needs of older individuals as an alternative to institutional care. The author affirmed that legislation, which will enable the implementation of the process at the macro level, is pivotal for the deinstitutionalisation process. Teodorović \& Miščević (2014) presented the findings of an ad hoc working group which had established that the users of institutional accommodation were isolated from the broader community, compelled to communal living, and lacked a control over their lives and the decisions that impacted their lives, as well as that the institutional demands often took precedence over the individual needs of those who required these services. Moreover, the social workers employed at retirement homes also observed a disregard for ensuring individualised work with those who required care services, a markedly bureaucratic approach to providing care, and the need for specific training in palliative care and working with individuals with psychoorganic disorders (Štambuk, Sučić \& Vrh, 2014).

When considering foster care as a form of care in the context of deinstitutionalisation, it is necessary to determine whether individuals who require foster families have any control over their lives, whether they use the resources of the community in which they live, whether they are isolated from the community, and whether the services provided to them are individualised or not (e.g., timing and quality of meals for individuals with diabetes or other medical conditions who have special dietary needs, or hygiene requirements). Comparing the accommodation services provided as part of institutional and noninstitutional care, such as foster care, we can conclude that they are similar in terms of their content (i.e., individuals in foster families and those in institutional care should have the same needs met). The difference between the two forms of care is reflected in the modalities of care provision in terms of facilities, equipment, number of professional and other workers, and its organisational structure. Contrary to other forms of care, legal regulations do not require foster care providers to have a specific educational profile, and the individuals who live 
Skrb u udomiteljstvu pružaju udomitelji čiji nužni obrazovni profil nije zakonski propisan kao što je u drugim oblicima skrbi, a korisnici žive s njima $\mathrm{u}$ istom stambenom prostoru i naglasak je stavljen na obiteljsko ozračje jer se skrb pruža malom broju korisnika.

\section{UDOMITELJSTVO I TEORIJA PRIVRŽENOSTI}

Teorija privrženosti nastala je sredinom 20 . stoljeća kada je engleski psihijatar i psihoanalitičar John Bowlby ukazao na značaj i ulogu ranih odnosa djeteta s majkom i taj odnos definirao kao afektivnu povezanost (Bowlby, 1988). Afektivna povezanost predstavlja specifičan, odnos koji se u najranijem djetinjstvu uspostavlja između majke i djeteta (Stefanović-Stanojević, Stanojević i Anđelković Stefanović, 2010). Bowlbyjeva teorija temelji se na emocionalnoj vezi između primarnog skrbnika, najčešće majke, i dijeta. U ovoj teoriji naglašeno je kako stvaranje ranih veza i kvaliteta brige u dojenačkoj dobi predstavlja temelj za kasnije funkcioniranje pojedinca i formiranje privrženog stila ponašanja. Prema teoriji privrženosti veza između djeteta i primarnog skrbnika od velike je važnosti za pravilan emocionalni i socijalni razvoj osobe i utječe na niz procesa u kasnijem životu. Je li dijete razvilo sigurnu ili nesigurnu privrženost $\mathrm{s}$ primarnim skrbnikom također ima utjecaja na kvalitetu i održivost prijateljskih i romantičnih veza.

Teorija privrženosti u kontekstu udomiteljstva promatrana je isključivo kroz udomiteljstvo djece. Kada je u pitanju izdvajanje djece iz primarne obitelj, tada se udomiteljstvo smatra najboljim oblikom skrbi. Neovisno o iskustvu u primarnoj obitelji, već sam čin izdvajanja djeteta iz njegove obitelji predstavlja značajan prekid emocionalnih veza s figurom privrženosti, a mnoga istraživanja pokazuju da to predstavlja značajan čimbenik rizika (Ajduković, Kregar Orešković i Laklija, 2007). Nadalje autorice navode da udomiteljstvo iz perspektive teorije privrženosti može imati dvostruku ulogu u smanjivanju problema vezanih uz privrženost, odnosno da neka istraživanja pokazuju da djeca odvajanje od roditelja doživljavaju manje stresnim ako su smještena $u$ udomiteljske obitelji, a ne $u$ institucije. with them in the same residential unit are integrated into the family environment since they deliver foster care to a small number of individuals.

\section{FOSTER CARE AND ATTACHMENT THEORY}

Attachment theory originated in the mid-twentieth century with John Bowlby, an English psychiatrist and psychoanalyst, highlighting the impact and the role of early relationships between children and their mothers: he defined this relationship as affective attachment (Bowlby, 1988). Affective attachment represents a specific relationship between mothers and their children that is established in early childhood (Stefanović-Stanojević, Stanojević \& Anđelković Stefanović, 2010). Bowlby's theory is based on the emotional bond between the primary caregiver, most often the mother, and the child. It stresses that the creation of early ties and the quality of care in infancy represents a foundation for an individual's behaviour in the future and the formation of the attachment style. According to the attachment theory, the ties between children and their primary caregivers are pivotal for healthy emotional and social development of individuals, which in turn affects many other processes later in life. Whether a child has developed a secure or insecure attachment with the primary caregiver also has an impact on the quality and sustainability of friendship and romantic relationships.

Attachment theory in the context of foster care was applied exclusively to foster care for children. Foster care is considered the preferred form of care when children are removed from their birth families. Regardless of their experiences in the birth family, the act of removing children from their families represents a significant disruption in emotional bonds with their attachment figure, and hence a considerable risk factor (Ajduković, Kregar Orešković \& Laklija, 2007). The authors also noted that, from the attachment theory standpoint, foster care can hence assume a dual role in relieving difficulties linked to attachment, (i.e.,) certain studies demonstrate that children experience the separation from their parents as less stressful if they are placed in foster families, instead of institutions.

The principal feature of foster care involves providing care to fewer individuals in a family 
Glavna je odlika udomiteljstva pružanje skrbi manjem broju korisnika u obiteljskoj atmosferi budući da svakoj smještenoj osobi pruža iskustvo života u obitelji. Vodeći se teorijom privrženosti bila je vođena i značajna kampanja UNICEF-a Svako dijete treba obitelj koja se odvijala tijekom 2005. i 2006. godine i promicala udomiteljski tip smještaja za djecu izdvojenu iz obitelji te rane intervencije u obiteljima koje su rizične za izdvajanje djece kako bi se roditelji osnažili i pružili dovoljno dobru skrb za djecu (Ajduković, Kregar Orešković i Laklija, 2007). Žižak (2008) ističe da se samo u obiteljskom domu dijete može naučiti svemu što čini uobičajenu obiteljsku svakodnevnicu te osjetiti pripadnost i podršku. Udomiteljstvo kao oblik skrbi za djecu daje djetetu priliku da s udomiteljem razvije novi oblik privrženosti, a djetetu se pružanjem pomoći i podrške omogućava prihvaćanje prošlosti i potiče spremnost za razvijanje novih odnosa.

Udomiteljstvo za osobe starije životne dobi kroz perspektivu teorije privrženosti u domaćoj stručnoj i znanstvenoj literaturi nije razmatrano premda bi se moglo promatrati u okviru kvalitetne funkcionalne prilagodbe u kojoj bi se, osim instrumentalne podrške, osobama starije dobi omogućavalo što više autonomije, kontrole nad osobnim životom i poticanje što češće interakcije s udomiteljima i s članovima obitelji. Privrženost u odrasloj dobi definira se kao afektivna veza koju karakterizira tendencija traženja i održavanja bliskosti s drugom osobom, naročito kad je osoba pod stresom. Iako je teorija privrženosti nastala kako bi se objasnio utjecaj emocionalne veze između djeteta i majke u ranom životnom razdoblju, već je Bowlby smatrao da privrženo ponašanje postaje organizirano unutar ličnosti pojedinca i određuje emocionalne veze tijekom cijelog njegova života (Kamenov, 2006). Većina dostupnih istraživanja privrženosti u odrasloj dobi orijentirala su se isključivo na privrženost u ljubavnim odnosima dok u novije vrijeme privrženost prema prijateljima, članovima obitelji i drugim bliskim osobama dobivaju također svoj značaj. Također privrženost se pokazala kao važna varijabla za objašnjenje mnogih doživljaja i ponašanja koji ukazuju na više ili manje funkcionalnu prilagodbu pojedinca različitim životnim događajima (Kamenov, 2006). environment since it offers the family life experience to each person placed in a foster family. Under the guise of attachment theory, UNICEF led a noteworthy campaign, "Every child needs a family", in 2005 and 2006. The campaign promoted foster care for children removed from their families, including early intervention in families at risk of having their children removed, to empower parents to provide adequate care to children (Ajduković, Kregar Orešković \& Laklija, 2007). Žižak (2008) pointed out that children can experience everyday family life, acceptance, and support only in a family home. Foster care as a form of child care allows children to develop new forms of attachment with their foster parent, accept the past, and prepare themselves to engage in new relationships through the assistance and support received in the foster home.

Until now, Croatian professional and scientific literature has not approached foster care for older persons through the perspective of attachment theory. Although it could be viewed as part of a high-quality functional adjustment in which, in addition to instrumental support, older individuals would be provided with as much autonomy as possible, as well as control over their personal lives, and they would be encouraged to engage more frequently in interactions with foster care providers and family members. Attachment at an adult age is defined as an affective tie, marked by the tendency to seek and maintain closeness with another person, particularly when a person is suffering stress. Although the attachment theory was developed to interpret the impact of the emotional bond between a child and a mother in early life, Bowlby further considered that the attachment behaviour became structured within each personality, determining different emotional relationships for a lifetime (Kamenov, 2006). Most research studies on attachment at an adult age have thus far focused exclusively on romantic relationships, while recent studies have increasingly recognised the significance of attachment to friends, family members, and other close individuals. Moreover, attachment emerged as a significant variable for explaining different experiences and behaviours, indicating a more or a less successful functional adjustment of an individual to changing life circumstances (Kamenov, 2006). 
Ana Štambuk, Marija Penava Šimac: Prikaz udomiteljstva kao oblika skrbi za osobe starije životne dobi u Hrvatskoj / An overview of...

\section{UDOMITELJSTVO KROZ PRIZMU SOCIJALNE MREŽE I SOCIJALNE POTPORE/PODRŠKE}

\subsection{Socijalna mreža}

Socijalna mreža jest društvena pojava koja omogućuje nesmetanu razmjenu resursa među akterima koji pripadaju istim i različitim skupinama i na taj način omogućava prevladavanje granica koje postavljaju različiti socijalni fenomeni (skupine, organizacije, udruženja i sl.), intenzivirajući i obogaćujući socijalne interakcije (Janković i Pandža-Ferenček, 1994). Sa sociološkog stajališta društvo se sastoji od mreže raznih odnosa između individua koje su u međusobnoj interakciji, a glavni predmet proučavanja sociologije u kontekstu socijalnih mreža jesu određeni obrasci i forme u koje se ljudi udružuju i stupaju u interakcije (Sokolovska i Škorić, 2012).

Dobrotić i Laklija (2012) navode da socijalnu mrežu čini polje formalnih i neformalnih odnosa pojedinaca unutar kojih se omogućuje razmjena usluga, informacija i drugih dobara. Iz perspektive socijalnih mreža udomiteljstvo za osobe starije životne dobi predstavlja formalni odnos između udomitelja i starijih osoba unutar kojega se osobama starije životne dobi pružaju usluge smještaja. Žganec (1993) iznosi da kada su u pitanju socijalne mreže ne govorimo o teoriji već o fenomenu pri čemu ističe da treba razlikovati ,prirodne mreže“ kao prirodnu zajedničku povezanost poput srodstva ili susjedstva od „umjetno“ nastalih ustanova i drugih oblika socijalnih mreža koje nastaju temeljem određenih, uglavnom ograničenih interesa ili problema. Socijalne mreže, odnosno mreže socijalnih odnosa, razlikuju se po obilježjima kao što su gustoća, veličina i kanali međusobne povezanosti. Isto tako kod mreža treba razlikovati njihov sadržaj, usmjerenje, trajnost, intenzitet, učestalost interakcija i dr.

Cho (2007) navodi da postoje dvije glavne podteorije u sklopu društvenih/socijalnih mreža: teorija usmjerena na zadatke i hijerarhijsko-kompenzacijska teorija. Teorija usmjerena na zadatke kategorizira društvenu mrežu kroz primarne, neformalne i formalne grupe. Prema ovoj teoriji svaka društvena mreža ima svoju svrhu i prirodu jer se potrebe koje se zadovoljavaju u stvorenim mrežama razlikuju ovisno o tipu mreže i odnosa

\section{FOSTER CARE FROM THE PERSPECTIVE OF THE SOCIAL NETWORK AND SOCIAL SUPPORT}

\subsection{Social network}

The social network represents a social phenomenon that allows agents from the same or different groups to exchange resources freely and thus overcome the boundaries imposed by other social phenomena (groups, organisations, and associations): concurrently, this intensifies and enriches social interactions (Janković, 1993). From the sociological perspective, a society consists of a network of various relationships between interacting individuals, and the principal subject of sociological research in the context of social networks involves specific patterns and associations that people join and use for interaction (Sokolovska \& Škorić, 2012).

Dobrtić and Laklija (2012) highlighted that the social network consists of a field of formal and informal relationships that allows individuals to exchange services, information, and other goods. From the perspective of social networks, foster care for older persons denotes a formal relationship between foster care providers and older persons where older individuals in need are provided with accommodation services. Žganec (1993) affirmed that social networks represented a phenomenon, rather than a theory. The author further highlighted the difference between "natural networks" as natural mutual ties, such as kinship or neighbourhoods, and "artificially" constructed institutions and other forms of the social network, based on specific, and generally limited, interests and issues. Social networks or networks of social relationships differ in their attributes, including density, size, and channels of mutual connection. Likewise, networks were different in terms of their content, direction, duration, intensity, and frequency of interactions.

Cho (2007) states that there are two main sub-theories within social networks: task-oriented theory and hierarchical compensation theory. Taskoriented theory categorises the social network as primary, informal, and formal groups. According to this theory, each social network has its purpose and characteristics because the needs that are met in constructed networks differ depending on the network type and the relationships (formal/informal). 
(formalni/neformalni). Ako se gleda sa stajališta starijih osoba, priroda i svrha mreže ovisit će o tome radi li se o prirodnoj ili umjetnoj mreži.

Hijerarhijsko-kompenzacijska teorija usredotočena je na važnost korisnika kao primatelja skrbi, a temelji se na odnosu između starije osobe i pružatelja skrbi. Prema ovoj teoriji starijim osobama skrb primarno pružaju supružnici, zatim djeca, rodbina, prijatelji i susjedi. Ako nitko od navedenih ne može pružiti skrb tada dolaze u obzir formalni pružatelji skrbi.

Uzimajući u obzir gore navedeno, može se zaključiti da teorija vezana za zadatke $u$ fokus stavlja potrebe koje će biti zadovoljene unutar socijalne mreže dok hijerarhijsko-kompenzacijska teorija u fokus stavlja odnos koji korisnik ima unutar socijalne mreže s pružateljem skrbi.

\subsection{Socijalna potpora/podrška}

Janković i Pandža-Ferenček (1994) opisuju da socijalna potpora predstavlja širi i općenitiji pojam i odnosi se na velik broj društvenih međuodnosa usmjerenih više ili manje organiziranom pružanju pomoći. Uchino (2004) je socijalnu potporu konceptualizirao kroz funkcije koje pružaju socijalni odnosi. Sladović Frasnz i Mujkanović (2013) navode da se socijalna podrška/potpora definira kao postojanje ili dostupnost osoba na koje se oslanjamo, koje nam daju do znanja da se o nama brinu, vole nas i cijene te da sadržava dva osnovna međusobno neovisna elementa: a) percepciju o dovoljnom broju dostupnih osoba na koje se možemo osloniti u slučaju potrebe i b) stupanj zadovoljstva koji pruža dostupna podrška.

Winnbust i sur. (1988, prema Despot Lučanin, 2003) navode dimenzije socijalne podrške koje bi se mogle operacionalizirati $i$ istraživati:

1. Socijalna podrška kao stupanj integracije osobe prema kojoj socijalni odnosi daju stabilne socijalne uloge i socijalno funkcioniranje osobe i u vrijeme socijalnih promjena,

2. Socijalna podrška kao subjektivan doživljaj odnosi se na procjenu kvalitete socijalnih odnosa pojedinca,

3. Socijalna podrška kao percipirana pomoć drugih ljudi - osjećaj osobe da u kriznim ili stresnim situacijama može računati na različi-
From the point of view of older persons, the characteristics and the purpose will depend on whether it is a natural or artificial network. The hierarchical compensatory theory focuses on the importance of the individual who is the recipient of care, and is based on the relationship between an older individual and a care provider. According to this theory, spouses, children, family, friends, and neighbours represent the primary care providers for older individuals. Formal care providers are considered only when the primary care providers are not available to provide care. Taking into account the above, it can be concluded that the task-oriented theory emphasises the needs met within the social network, while the hierarchical compensation theory stresses the relationship of individuals in need and care providers within the social network.

\subsection{Social support}

Janković (1993) describes social support as a broader and more general term referring to numerous social relationships directed at the provision of organised assistance, to a lesser or greater extent. Uchino (2004) conceptualised social support as functions emerging from social relationships. Sladović Franz \& Mujkanović (2013) state that social support is defined as the presence or availability of individuals one could rely on, and those who showed that they cared, loved, and appreciated us. Social support consists of two key mutually independent elements: a) perception of a sufficient number of available individuals one could rely on in case the need arises, and b) degree of satisfaction with the support available.

Winnbust et al. (1988, in Despot Lučanin, 2003) listed the dimensions of social support that could be operationalised and researched:

1. Social support as the degree of integration of a person according to which social relationships provide stable social roles and social functioning of an individual even in times of social change

2. Social support as a subjective experience refers to the assessment of the quality of social relationships of an individual

3. Social support as perceived help from other people refers to an individual's feeling that in situations of crisis or stress they can count on 
te vidove pomoći drugih ljudi - pa se ni sam stresni događaj ne mora percipirati kao stresan,

4. Socijalna podrška kao stvarno primljena pomoć drugih ljudi koja može biti emocionalna, izraz poštovanja, instrumentalna podrška pružanja usluga i stvari te informacijska.

Ako promatramo udomiteljstvo za starije osobe kroz prizmu socijalne podrške, tada se usmjeravamo na podršku koju udomitelji pružaju starijim osobama, na kvalitetu dobivene pomoći i podrške te na stupanj zadovoljstva. Janković i PandžaFerenček (1994) navode da su prema mišljenju brojnih autora definicije socijalne potpore „mutne“, „neprecizne“ i ,cirkularne“. Navode da razlozi leže u tome što postoje velike teškoće u mogućnosti definiranja subjektivnih emocionalnih kvaliteta, stupnja bliskosti, uzajamne komunikacije, njihove učestalosti, kvalitete i što je najvažnije, njihovih posljedica. Odnose među ljudima teško je mjeriti zbog njihove suptilnosti i dinamike. Socijalna podrška podrazumijeva dostupnost resursa u socijalnoj okolini koji pojedincu pružaju podršku u svakodnevnom životu te u kriznim situacijama i time pridonose njegovoj dobrobiti. Na socijalnu se podršku gleda kao na multidimenzionalan koncept (Dobrotić i Laklija, 2012) koji uključuje instrumentalnu, socioekonomsku i informacijsku podršku. Instrumentalna se odnosi na akcije koje vrše drugi, a omogućuje ispunjenje uobičajenih odgovornosti u okviru uloga. Sociopsihološka pomoć podrazumijeva iskazivanje ljubavi, brige, simpatije i pripadnosti grupi. Informacijska obuhvaća komunikaciju činjenica ili mišljenja, kao npr. savjete i informacije koje mogu olakšati životne uvjete osobe (Katilović, 2016). Ograničenje socijalne potpore proizlazi iz toga što se u konceptualizaciji potpore više naglašavaju psihosocijalni aspekti nego fizički aspekti (Sabolić i Vejmelka, 2015).

Freund, Nikitin i Ritter (2009) navode kako socijalna podrška ima pozitivan utjecaj na tjelesno i mentalno zdravlje. Empirijski dokazi sugeriraju da je socijalna podrška vrlo značajna u starijoj dobi te da vrijeme provedeno s bliskim prijateljima može biti jedna od važnih prednosti produljenja života starijih osoba. Općenito se smatra da socijalna podrška utječe na tjelesno i mentalno zdravlje djelovanjem na emocije, kogniciju i ponašanja (Cohen, Underwood i Gottlieb, 2000). Istraživanje koje je different types of help from other people, so that the stressful event itself does not even have to be perceived as stressful.

4. Social support as the help received from other people that can be emotional, an expression of respect, instrumental support of providing services and things, and information support.

If we consider foster care for individuals from the perspective of social support, then we focus on the support that foster care providers provide to older persons, such as the quality of assistance and support received, and the degree of satisfaction. Janković (1993) stated that many authors considered the definition of social support as "vague", "imprecise", and "circular". because there are significant difficulties with defining the subjective, emotional attributes, the degree of affection, communication, as well as their frequency, quality, and, notably, their effects. Human relationships are difficult to measure because they are subtle and dynamic. Social support presumes the availability of resources in the social environment that ensured support to individuals in everyday life and in situations of crisis, thus contributing to their well-being. Social support was further regarded as a multidimensional concept (Dobrotić \& Laklija, 2012) that comprised of instrumental, socioeconomic, and informational support. The instrumental support refers to actions performed by others and allows fulfilling ordinary responsibilities within different roles. Psychosocial support includes expressions of love, care, sympathy, and belonging to a group. Informational support involves exchanging facts and opinions, such as advice and information that might improve one's living conditions (Katilović, 2016). The limitations to social support ensues from emphasising psychosocial aspects over the physical aspects of support within the context of conceptualising support (Sabolić \& Vejmelka, 2015).

Freund, Nikitin \& Ritter (2009) stated that social support positively impacts physical and mental health. Empirical evidence suggests that social support is crucial at an advanced age, and that time spent with close friends might be one of the significant advantages in extending the life expectancy of older persons. Overall, it was considered that social support influenced physical and mental health by acting on emotions, cognition, and behaviours (Cohen, Underwood \& Gottlieb, 2000). 
provedeno u Republici Hrvatskoj 90-ih godina potvrdilo je da su vrsta i količina socijalne podrške kao i veličina socijalne mreže vrlo važne odrednice kvalitete i dužine života (Despot Lučanin, Lučanin i Havelka, 2006). Despot Lučanin (2008) navodi brojna istraživanja koja su pokazala da su različiti oblici socijalne podrške povezani s promjenama u tjelesnom i psihičkom zdravlju starijih osoba te da je manji mortalitet starijih osoba povezan s velikom socijalnom podrškom. S druge strane u literaturi se spominje i negativni efekt koji može proizvesti socijalna podrška. Tako primjerice instrumentalna ili emocionalna socijalna podrška, iako mogu biti pružene s najboljom namjerom, mogu kod bolesnika smanjiti vlastiti osjećaj kontrole što dovodi do stanja bespomoćnosti i ovisnosti o drugim osobama te do povećanja simptoma depresivnosti (Katilović, 2016). Vručinić (2012) navodi da je socijalna podrška koncept blisko povezan s konceptom socijalne mreže odnosno vezom s obitelji, prijateljima, susjedima i drugim. Stoga je u planiranju skrbi za starije osobe bitno procijeniti koja socijalna mreža (formalna i/ili neformalna) može pridonijeti dobrobiti i boljoj kvaliteti života, vodeći brigu o očuvanju njihova dostojanstva te poštujući njihova ljudska prava.

\section{PRIKAZ ISTRAŽIVANJA O IZVANINSTITUCIJSKOJ SKRBI ZA STARIJE OSOBE}

S obzirom na to da istraživanja o udomiteljstvu osoba starije životne dobi u Hrvatskoj nisu provedena (osim jednoga o kojem će u sljedećem poglavlju biti riječi), ovdje ćemo se osvrnuti na širi kontekst izvaninstitucijske skrbi za starije osobe, odnosno prikazati istraživanja koja su o ovoj temi provedena.

Istraživanju koje su proveli Havelka i suradnici (2000) bio je cilj razviti modele otvorene skrbi za osobe starije životne dobi, istražiti stanje te dostupnost različitih zdravstvenih, socijalnih i drugih usluga, kao i njihove potrebe za takvim uslugama. Rezultati istraživanja pokazali su da su osobama starije životne dobi najdostupnije i najpotrebnije usluge zdravstvene skrbi, nešto su manje dostupne, ali prilično potrebne i usluge pomoći u kući, a najmanje su dostupne, iako potrebne, usluge vezane za slobodno vrijeme i aktivnosti. S ciljem
Research conducted in Croatia in the 1990s further established that the type and extent of social support, as well as the size of the social network, represented noteworthy determinants of the quality of life and life expectancy (Despot Lučanin, Lučanin \& Havelka, 2006). Despot Lučanin (2008) listed numerous studies that had linked different forms of social support to changes in physical and mental health of older persons, indicating a correlation between lower mortality among older persons and higher levels of social support. However, literature also cautions against the adverse effect of social support. For example, instrumental or emotional social support, even with the best of intentions, might lower the sense of personal control for some patients, leading to helplessness and dependence on others, as well as aggravated symptoms of depression (Katilović, 2016). Vručinić (2012) stated that social support is a concept that is closely related to that of the social network, involving ties with family, friends, neighbours, and other people. For this reason, when planning care for older persons, it is important to consider which social network (formal and/or informal) could contribute to their well-being and quality of life, while safeguarding the dignity and respect for the human rights of older persons.

\section{OVERVIEW OF RESEARCH ON NONINSTITUTIONAL CARE FOR OLDER PERSONS}

Since there have been no research studies on foster care for older persons in Croatia so far (except for one study discussed in the following section), this overview will reflect on the broader context of noninstitutional care for older individuals and present the existing research studies in the field. Havelka et al. (2000) aimed at developing models of open care for older persons, as well as understanding the status, availability, and need for health care, social welfare, and other services. Research results demonstrated that health care services were both widely available and requested often among older individuals, whereas household assistance was somewhat less available, yet quite in demand; services related to leisure activities were almost unavailable, although fairly required. Seeking to affirm noninstitutional forms of care, a 
afirmiranja izvaninstitucijskih oblika skrbi provedeno je evaluacijsko istraživanje u naseljima Drenovci, Đurići, Posavski Podgajci, Račinovci i Rajevo Selo i to u svrhu evaluacije pilot-projekta i procjene opravdanosti pružanja izvaninstitucijske usluge pomoći osobama starije životne dobi na uzorku od 164 ispitanika, korisnika programa. Pokazalo se da program značajno pridonosi poboljšanju kvalitete života osoba starije životne dobi. Njegovo provođenje pridonijelo je zapošljavanju određene skupine teže zapošljivih žena, a korisnicima programa bitno je olakšalo zadovoljavanje mnogih potreba, poglavito u obavljanju svakodnevnih kućanskih poslova te brizi o osobnoj higijeni i zdravlju (Boullete, 2003). Despot Lučanin i suradnici (2006) ispitivali su povezanost između sociodemografskih obilježja, samoprocjene tjelesnoga i psihičkoga zdravlja te zadovoljstva osoba starije životne dobi i njihovih potreba za uslugama skrbi. Ispitano je 2911 osoba starije životne dobi iz svih krajeva Republike Hrvatske, prosječne dobi od 73 godine. Nalazi su pokazali da se učinkovitijim pružanjem usluga skrbi može postići bolja kvaliteta življenja osoba starije životne dobi. Pravodobnim i primjerenim intervencijama u lokalnoj zajednici, prije svega prema procjeni općeg stanja, zadovoljstva životom i potreba starije osobe, može se spriječiti pogoršanje kvalitete življenja.

Isto tako provedeno je istraživanje s ciljem ispitivanja demografske osobitosti starijeg stanovništva Istre, njihova obiteljskog i zdravstvenog stanja, zadovoljstva životom, potreba i dostupnosti različitih usluga skrbi, te usporedbe s obilježjima starijeg stanovništva Zagreba, Dalmacije i Slavonije (Petrak, Despot Lučanin i Lučanin 2006). U navedenom istraživanju ispitane su 1 262 osobe starije životne dobi, prosječne dobi 74 godine. Usporedbom osoba starije životne dobi s četiri područja Hrvatske utvrđeno je da se osobe starije životne dobi iz navedenih regija najviše razlikuju u dostupnosti usluga skrbi i količini socijalne podrške. Dobiveni rezultati potvrđuju da bi programe skrbi trebalo organizirati na razini lokalne zajednice, što više prilagođene potrebama i mogućnostima pojedinaca, počevši od procjene stanja i potreba, procjene i planiranja troškova te praćenja kvalitete pruženih usluga i učinkovitosti skrbi, čime bi se postigla bolja kvaliteta življe- research assessment conducted in the villages of Drenovci, Đurići, Posavski Podgajci, Račinovci and Rajevo Selo evaluated a pilot project and the merits of providing noninstitutional services of assistance to older individuals based on a sample of 164 respondents (i.e.,) program users. The results demonstrated that the program contributed significantly to the quality of life of older individuals. The implementation of the program contributed to employment of the women who were at high risk of unemployment: these women facilitated meeting the needs of the program users, particularly with respect to quotidian household chores, personal hygiene, and health (Boullete, 2003). Lučanin et al. (2005) examined the correlation between sociodemographic factors, self-assessment of physical and mental health, satisfaction, and the need for care services among elderly based on a sample of 2,911 individuals, aged 73 years on average, who were surveyed across the Republic of Croatia. Their findings suggest that more efficient provision of care services could raise the quality of life for older persons. Timely and adequate interventions in the local community, based primarily on an assessment of the general condition, life satisfaction, and needs, might also offset a decline in the quality of life of these older individuals.

Another research study examined the demographic characteristics of older persons population in Istria $(n=1,262$, average age $=74$ years $)$, including their family and health condition, life satisfaction, needs, and the availability of different care services, and compared them to the attributes of older persons population in Zagreb, Dalmatia, and Slavonia (Petrak, Lučanin \& Lučanin 2006). The authors demonstrated that regional differences affecting older individuals mostly concerned the availability of care services and the extent of social support. These results confirmed that care services should be organised at the local community level, and tailored to the needs and abilities of individuals to the greatest extent possible; starting from the assessment of condition and needs, cost assessment and planning, as well as monitoring the quality of performed services and efficacy of care, which would then raise the quality of life of older individuals and their families. Furthermore, a survey was conducted regarding living conditions in 
nja osoba starije životne dobi i njihovih obitelji. Također provedeno je i istraživanje vezno uz uvjete života u Gorskom kotaru u kojem je oko samo 3\% ispitanika izjavilo da su primili neki oblik pomoći lokalne samouprave, pri čemu dobivenu pomoć ne smatraju adekvatnom. Velik broj ispitanika izjavio je da im je pomoć nužna, no predstavnici lokalne samouprave ne pokazuju nikakav interes za njih (Spitek-Zvonarević, Takšić, 2004). U Istarskoj županiji 2004. godine provedeno je istraživanja o stanju, potrebama i zadovoljstvu životom osoba starijih od 60 godina u Istarskoj županiji (Plavšić, Ambrosi-Randić, 2005). U zaključku se navodi da su najzadovoljnije osobe koje žive u manjim gradovima i mjestima.

Za potrebu izrade Strategija socijalne skrbi za starije osobe nadležno Ministarstvo je provelo akcijsko istraživanje ispitivanja potreba starijih osoba (MSPM, 2013) na uzorku od 1860 osoba starije životne dobi koje su tijekom lipnja srpnja i kolovoza došle u kontakt sa stručnjacima iz centra za socijalnu skrb. Rezultati su pokazali da osobe starije životne dobi smatraju potrebnijim izvaninstitucijski oblik skrbi u odnosu na institucijski oblik skrbi kako bi što duže bile neovisne i samostalne.

Novijeg je datuma istraživanje provedeno u općini Desinić te je utvrđeno da bi svega $8 \%$ osoba starije životne dobi htjelo živjeti u domu za starije, a $92 \%$ osoba starije životne dobi željelo bi život provesti u vlastitom domu (Stiplošek Horvat, 2017). Navedeno nam daje naslutiti da sudionici smatraju kako im je bolje u njihovu domu i lokalnoj zajednici. Vezano za korištenje usluga u budućnosti najveći broj osoba starije životne dobi koristilo bi usluge gerontodomaćice, kućanskih poslova i fizikalne terapije.

Vrlo značajna istraživanja na ovu temu provedena su u Srbiji 2013. godine (Vuković, Vuković i Cvejić, 2013) gdje je, između ostalog, mjerena dimenzija stupnja zadovoljstva korisnika uslugom pomoć u kući. Podaci istraživanja govore o tome da su korisnici usluge vrlo zadovoljni posvećenošću i stručnošću gerontodomaćica. Također je i usluga dnevnog boravaka za osobe starije životne dobi ocijenjena pozitivno, odnosno korisnici usluge iskazali su visok stupanj zadovoljstva i to najviše radom osoblja (njihovom posvećenošću, strpljenjem i ljubaznošću). Također je ispitivano i
Gorski Kotar, where only about 3\% of respondents stated that they had received some form of local self-government assistance, and did not consider the assistance received adequate. A large number of respondents stated that they needed assistance, but local self-government representatives did not show any interest in them (Spitek - Zvonarević, Takšić, 2004). In 2005, a study conducted in the Istria County regarding the condition, needs, and life satisfaction of individuals older than 60 years showed that the most satisfied individuals are those living in smaller towns and settlements in the Istria County ( Plavšić, Ambrosi-Randić, 2005).

For the purpose of preparing the Strategy for Social Welfare for Older Persons, the line ministry conducted an action research project to assess the needs of older persons (MSPM, 2013), based on a sample of 1,860 individuals who contacted social welfare centre experts in June, July, and August. The results demonstrated that older individuals consider noninstitutionals form of care more necessary than institutional forms of care in order to be self-sufficient and independent for as long as possible.

More recently, research was conducted in the municipality of Desinić, where only $8 \%$ of older individuals wanted to live in retirement homes, and 92\% favoured their own homes (Stiplošek Horvat, 2017). This suggests that respondents believe they are better off in their own homes and the local community. In terms of services they would use in the future, most of the older individuals mentioned senior housekeeping services, assistance with household chores, and physical therapy.

Another highly relevant study, conducted in Serbia in 2013 (Vuković, Vuković \& Cvejić, 2013), measured the dimension of the level of satisfaction with the household assistance service, among other aspects. The findings show that service users praised the dedication and professionalism of senior housekeeping services. The day care services for older individuals were also rated highly (i.e.,) the users of the service expressed a high degree of satisfaction, especially with the work of the staff (their dedication, patience, and kindness). The social inclusion of people over 65 years of age was also examined (Babović et al., 2018), and it was found that services for older individuals should 
područje socijalne uključenosti osoba starijih od 65 godina (Babović i sur., 2018) pri čemu je ustanovljeno da je potrebno povećati raznovrsnost usluga za osobe starije životne dobi koje su nedovoljne ili nedostupne (dnevni centri, klubovi, pomoć u kući).

U nedavno provedenom istraživanju na području Bosne i Hercegovine u cilju unapređenja stanja osoba starije životne dobi jedna je od preporuka deinstitucionalizacija skrbi za starije (Kepeš i sur., 2019). Naime navodi se da je institucionalizacija izuzetno skupa te nije uvijek najbolje rješenje i u najboljem interesu svake starije osobe koja nije u mogućnosti brinuti se za sebe. Deinstitucionalizacija i pružanje različitih usluga koje iziskuju manje financijskih sredstava od bolničkog, odnosno domskog smještaja, predstavljaju moguća rješenja koja su u većini slučajeva istovremeno i u najboljem interesu starije populacije, navodi se u navedenom istraživanju. Također nedavno provedeno istraživanje na području grada Zagreba o obiteljskim njegovateljima starijih osoba ukazuje na alarmantne podatke o zanemarenim potrebama starijih osoba i njihovih obiteljskih njegovatelja (Štambuk, Rusac i Skokandić, 2019). Naime njegovatelji ističu da im je u skrbi za osobe starije dobi potrebna dodatna pomoć fizioterapeuta (32\%), doplatak za pomoć i njegu (29\%), pomoć i njega u kući $(28,1 \%)$, jednokratna novčana pomoć $(23,9 \%)$, patronažna sestra $(22,7 \%)$, dok $18 \%$ ispitanika ističe potrebu za stacionarom. Možemo pretpostaviti da su ove potrebe još izraženije u ostalim, a posebno ruralnim i nerazvijenim djelovima Hrvatske.

\section{PRIKAZ ISTRAŽIVANJA O UDOMITELJSTVU OSOBA STARIJE ŽIVOTNE DOBI}

Na početku treba spomenuti da su istraživanja o udomiteljstvu starijih osoba u Republici Hrvatskoj zanemarena, odnosno da ih gotovo nema. Jedino je istraživanje provedeno na području Baranje, a imalo je za cilj utvrditi razliku između udomitelja za djecu i udomitelja za odrasle osobe. Rezultati istraživanja pokazali su da se ove dvije skupine udomitelja ne razlikuju s obzirom na sociodemografska obilježja osim u razini obrazovanja pri be diversified, especially those that are insufficient or unavailable (day care centres, clubs, household assistance).

To improve the position of older individuals, a recent study from Bosnia and Herzegovina advocated deinstitutionalising care services for older persons (Kepeš et al., 2019). It argues that institutionalisation is extremely expensive and it did not represent the most appropriate solution, in the best interest of every older individual who was no longer able to look after themselves. According to this study, deinstitutionalisation and provision of various services, which cost less than accommodation in hospitals or retirement homes, represent potential solutions that are also in the best interest of most senior citizens. Furthermore, a recent study in the city of Zagreb on family caregivers of older individuals yielded distressing findings on disregarded needs of older persons and their family caregivers (Štambuk, Rusac \& Skokandić, 2019). In the context of care for older individuals, caregivers stress the need for additional assistance from physiotherapists (32\%), allowances for assistance and care $(29 \%)$, assistance and care provision at home $(28.1 \%)$, one-time allowances $(23.9 \%)$, home care nurses $(22.7 \%)$, and the need for an infirmary $(18 \%)$. We can assume that these needs are even more acute in other parts of Croatia, especially in rural and underdeveloped locations.

\section{OVERVIEW OF RESEARCH ON FOSTER CARE FOR OLDER PERSONS}

Overall, very little research has been conducted on foster care for older individuals in the Republic of Croatia. The sole research study, conducted in the area of Baranja, aimed at determining the differences between foster care providers for children and adults (Savanović, 2010). This study demonstrated that the two groups of foster care providers do not differ significantly in terms of sociodemographic characteristics, except for their education levels: foster care providers for children had higher qualifications. The differences were reflected in the frequency of contact between foster care providers and social welfare centres, and other general challenges for foster care providers. Foster parents encountered significantly fewer general difficulties 
čemu su udomitelji djece obrazovaniji. Razlike su se očitovale u učestalosti komunikacije udomitelja i centra za socijalnu skrb te u općim poteškoćama s kojima se suočavaju u obavljanju udomiteljstva. Udomitelji za djecu su iskazivali statistički značajno manje općih poteškoća u obavljanju udomiteljstva od udomitelja za odrasle osobe, dok su udomitelji za odrasle iskazivali više zadovoljstva sobom kao udomiteljima za razliku od udomitelja za djecu (Savanović, 2010).

Kada je u pitanju udomiteljstvo u svijetu, treba spomenuti provedeno istraživanje vezano uz modele udomiteljstva u Europi (Laklija, 2011). Ovo istraživanje daje odgovor na pitanje postoji li udomiteljstvo za odrasle osobe. Podaci dobiveni u istraživanju pokazuju da je udomiteljstvo za osobe starije životne dobi, osim u Republici Hrvatskoj, prisutno i u drugim zemljama Europe kao što su Finska, Francuska, Poljska te Bosna i Hercegovina pri čemu se ističe da je u Bosni i Hercegovini ovaj oblik skrbi prisutan na normativnom nivou, ali nije zaživio u praksi.

U Poljskoj je udomiteljstvo za osobe starije životne dobi zakonski regulirano i pokriva skrb za osobe starije životne dobi i osobe s invaliditetom. Zanimljivo je da se pri pretraživanju službenih stranica poljske vlade (Podaci o udomiteljstvu odraslih osoba u Poljskoj, 2020) ne spominje udomiteljstvo kao oblik skrbi za osobe starije životne dobi već samo za djecu. Također na službenim stranicama vlade i nadležnog ministarstva za socijalnu skrb u Francuskoj ne spominje se mogućnost udomiteljstva za osobe starije životne dobi, a ne nalaze se ni znanstvena istraživanja o tome. Međutim pregledom mrežnih tražilica doznaje se da je ovaj oblik skrbi itekako prisutan u Francuskoj (The Connexion, 2020).

U Finskoj je provedeno istraživanje s ciljem dobivanja uvida u to kako udomitelji za odrasle osobe uspostavljaju granicu između privatnog i poslovnog života i to $u$ odnosu na prostornu i vremensku distancu te je u zaključku navedeno da je to jako otežano (Leinonen, 2020). Ideja o udomiteljstvu odraslih u Finskoj leži u tome da se potiče zbrinjavanje osoba starije životne dobi u kućama te da skrb o njima vode udomitelji koji nisu s njima rodbinski povezani i nisu formalno zaposleni u javnom sektoru. U Finskoj većina udomitelja pruža in foster care provision than foster care providers for adults. On the other hand, the latter expressed higher satisfaction with themselves as foster care providers than foster parents (Savanović, 2010).

Concerning the state of affairs with respect to foster care worldwide, we must mention another research study that reviewed different foster care models in Europe and aimed to answer questions such as "Does foster care for adults exist?" (Laklija, 2011). This study showed that foster care for older persons definitely exists in Croatia and other European countries, including Finland, France, Poland, and Bosnia and Herzegovina, but it should be noted that this form of care in Bosnia and Herzegovina is present merely on the normative level since it has not taken root in practice. In Poland, foster care for older persons is legally regulated and covers care for older individuals and people with disabilities. The official website of the Government of Poland (Data on foster care for adults in Poland, 2020) did not mention foster care as a form of care for older individuals, and focused only on children. Likewise, the official websites of the Government and the ministry in charge of social welfare in France did not suggest the foster care option for older individuals or provide any relevant scientific research. However, additional research on the Internet revealed that this form of care was, in fact, quite widespread in France (The Connexion, 2020).

A research study was conducted in Finland with the aim of gaining insight into the mechanisms by which foster care providers for adults established boundaries between personal and professional life, notably the distance in terms of space and time: the authors concluded that this remained quite challenging (Leinonen, 2020). In Finland, the concept of foster care for adults promoted care provision for older individuals in private households, performed by providers who were not related to the individuals in need, nor formally employed by the public sector. Most foster care providers in Finland offered short-term care against the backdrop of entirely decentralised social welfare and health care services.

In Great Britain, there is a form of care called "Shared Lives Plus" that offers several models of care: long-term accommodation, day care, reha- 
samo kratkoročnu njegu s time da je organizacija socijalne i zdravstvene skrbi decentralizirana $\mathrm{u}$ svim pogledima.

U Velikoj Britaniji prisutan je oblik skrbi Shared Lives Plus koji nudi više modela skrbi: dugotrajni smještaj, dnevni smještaj, rehabilitacijsku skrb, povremeni smještaj i skrb koji se pruža starijim osobama za vrijeme odmora njegovatelja te podršku i pomoć u kući starije osobe. Dugotrajni smještaj vrlo je sličan udomiteljstvu u Hrvatskoj. Naime on podrazumijeva smještaj i skrb o starijim osobama u obitelji njegovatelja. Nalazi istraživanja koja su provedena 2012. i 2013. govore da ovaj oblik skrbi ima prednosti za neke starije osobe jer promiče socijalnu uključenost, smanjuje izolaciju i usamljenost, promiče neovisnost i kontrolu te pruža emocionalnu podršku (Brookes, Callaghan 2014.; Brookes, Palmer, Callaghan 2016). Također uspoređujući ovaj oblik skrbi s drugim alternativnim oblicima skrbi, došlo se do nalaza da su starije osobe koje su koristile program Shared Lives Plus ocjenjivali ukupnu kvalitetu života višom od onih koji koriste alternativne usluge njege i podrške (Callaghan, Brookes, Palmer, 2017).

U Sjedinjenim Američkim Državama (SAD) najviše je provedenih istraživanja u ovom području (Braun, Rose 1986; Newman, Sherman 1979; Oktay, Vollandu 1987; Linn, Klett i Caffey 1980; Reinardyand, Kane 1999) pri čemu se udomiteljstvo definira kao život unutar malih skupina u kojima se nalazi smještaj i briga za osobe s oštećenjima, a licencirane su od strane države. U SAD-u je određen minimalan i maksimalan broj osoba koje mogu biti u udomiteljskoj skrbi i iznosi od tri do šest osoba ovisno o pojedinoj državi (Kane i Kane, 1980). Udomiteljstvo je u SAD-u regulirano posebnim propisima u 17 država dok je 13 država zadržalo fleksibilnost u postavljanju standarda za udomiteljstvo. Osim navedenog većina zemalja u SAD-u zahtijeva specijalizirano obrazovanje udomitelja za podršku određenoj populaciji poput odraslih s invaliditetom i osoba starije životne dobi s demencijom (U.S. Department of Health and Human Services Office of Disability, 2010). Važno je spomenuti da se u SAD-u udomiteljstvo osoba starije životne dobi zagovara u okviru koncepta života u zajednici. Tako je na Havajima (Braun i Rose, 1986.) provedeno istraživanje koje je imalo bilitation care, occasional accommodation, and care provided to older individuals when their caregivers are on leave, as well as support and assistance provided in elderly households. Long-term accommodation is very similar to foster care in Croatia, and refers to accommodation and care for older individuals in the caregiver's family. Further research conducted in 2012 and 2013 suggested that this form of care has benefits for some older individuals because it promotes social inclusion, reduces isolation and loneliness, promotes independence and control, and provides emotional support (Brookes, Callaghan 2014; Brookes, Palmer, Callaghan 2016). Furthermore, by comparing this form of care with other alternative forms of care, researchers realised that older individuals who used the "Shared Lives Plus" program rated their overall quality of life higher than those who used alternative care and support services (Callaghan, Brookes, Palmer, 2017).

A majority of research studies conducted in the field have been carried out in the United States (Braun, Rose 1986; Newman, Sherman 1979; Oktay, Vollandu 1987; Linn, Klett \& Caffey 1980; Reinardy \& Kane, 1999), where foster care is defined as life in smaller communities, licensed by the states, with accommodation and care services for individuals with disabilities. In the U.S., the stipulated minimum and maximum number of individuals in foster homes can range from 3-6 individuals, depending on the state (Kane \& Kane, 1980). Special regulations govern foster care across 17 states in the U.S., whereas 13 states retained flexibility in setting foster care standards. Moreover, most states in the U.S. require specialised training for foster care providers for support provided to certain populations, such as adults with disabilities and older individuals with dementia (U.S. Department of Health and Human Services Office of Disability, 2010). It is important to mention that, in the U.S., foster care for older persons is notably advocated for within the community-based living concept. A research study conducted in Hawaii (Braun \& Rose, 1986) aimed at assessing a senior foster family programme based on a sample of 40 couples who had been released from hospitals to foster families or nursing homes. Respondents were observed after six months of using the select- 
za cilj ocjenu programa gerijatrijske udomiteljske obitelji na uzorku od 40 parova koji su bili otpušteni iz bolnice u udomiteljstvo ili u domove za njegu. Ispitanici su promatrani nakon šest mjeseci korištenja odabranog tipa usluge i to u odnosu na pokretljivost, samozbrinjavanje, blagostanje i cijenu usluge. Korisnici koji su bili na smještaju u udomiteljskim obiteljima imali su bolje rezultate $u$ pogledu samostalnog funkcioniranja i brige o sebi, a cijena njihove usluge bila je niža i iznosila je $61 \%$ cijene usluge smještaja u domovima za starije. Autori istraživanja zaključuju da su širenje usluga u kući i udomiteljstvo dobra alternativa institucionalnoj skrbi za znatan broj gerijatrijskih bolesnika.

Također značajan doprinos u promicanju udomiteljstva predstavlja istraživanje u kojem je opisan program skrbi u zajednici te su prezentirani nalazi studije u kojoj je 112 osoba starije životne dobi slučajno raspoređeno i smješteno u dom za starije ili udomiteljsku obitelj (Oktay i Vollan, 1987). Skupine starijih osoba bile su nakon toga ispitivane svaka tri mjeseca. U ispitivanju su bili uključeni i njegovatelji. Studija je pokazala da osobe koje su bile smještene u udomiteljstvu imaju bolje rezultate u pogledu mentalnog statusa i samostalnog funkcioniranja te su bili optimističniji u pogledu konačnog odlaska iz skrbi. Nasuprot tome osobe koje su bile u institucijskom smještaju pokazale su veće zadovoljstvo te su sudjelovale u više društvenih i rekreativnih aktivnosti. Cijena usluge smještaja u udomiteljstvu bila je 17 posto niža od institucionalnog smještaja. Rezultati dobiveni u navedenom istraživanju ukazuju na to da udomiteljstvo može biti održiva alternativa za smještaj osoba starije životne dobi. Prema Linn, Klett i Caffey (1980) udomiteljstvo pruža bolje socijalno funkcioniranje i socijalnu prilagodbu. Udomiteljska obitelj alternativa je institucionalnoj skrbi jer korisnici dolaze $u$ obitelji koje im otvaraju srce i s njima dijele svoje živote (Hoffman i Romero, 1994). S druge strane Mehrotra i Kosloski (1991) ističu da se pod udomiteljstvom odraslih osoba podrazumijevaju raznoliki programi koji, iako predstavljaju važan element skrbi za osobe starije životne dobi, ipak nisu jasno i detaljno definirani. Također ne postoji konsenzus među stručnjacima o tome koji su ciljevi udomiteljstva za odrasle osobe, tko bi trebao biti smješten u takav oblik skrbi te kako se mjeri uspješnost ovog ed type of service in terms of mobility, self-care, well-being, and the price of services. Individuals placed in foster families achieved better results with respect to independence and self-care, while the price of services was lower, amounting to $61 \%$ of the nursing home service price. The authors concluded that the expansion of home-based services and foster care can represent a preferred alternative to institutional care for many senior patients.

Furthermore, the results of a research study describing a community-based care programme where 112 older individuals were randomly placed in retirement homes or foster families (Oktay \& Vollan, 1987) also contributed significantly to foster care promotion; groups of older individuals were subsequently surveyed on a quarterly basis, and caregivers were also involved in the study. The study indicated better results for individuals in foster care in terms of their mental health status and independent functioning, including a greater optimism regarding the prospects of ultimately leaving care. Conversely, individuals in institutional care expressed higher satisfaction and participated in more social and recreational activities. The price of foster care services was $17 \%$ lower than that of institutional accommodation. The results of this study indicate that foster care might be a sustainable alternative for the accommodation of older persons. According to Linn, Klett \& Caffey (1980), foster care enables improved social functioning and social adjustment. The foster family is an alternative to institutional care as individuals in need enter families who can offer emotional comfort and share their lives with them (Hoffman \& Romero 1994). On the other hand, Mehorta \& Kosloski (1991) highlighted that foster care for adults encompassed different programs that lack a clear and detailed definition, although they represented a significant aspect of care for older persons. Moreover, a consensus on the goals for adult foster care, and who should be placed in such a form of care has yet to be reached among professionals. The efficiency benchmarks need to further investigated before this type of care is utilised to its full potential.

\section{CONCLUSION}

The development of care for older persons should be based on the concept of the right of an 
oblika zbrinjavanja pri čemu je važno naglasiti da ukoliko se ne razriješe navedene nedoumice, ovaj oblik skrbi ostaje neiskorišten potencijal.

\section{ZAKLJUČAK}

Razvoj skrbi za starije osobe trebao bi se temeljiti na konceptu prava osobe starije životne dobi da sama odlučuje na koji način želi živjeti u starosti te sustavnom pristupu problematici. Stoga bi trebala postojati različita lepeza servisa i usluga, što se svakako za skrb o starijim osobama u Hrvatskoj ne može potvrditi. Naime autori koji se bave problematikom skrbi za starije osobe u Hrvatskoj navode različite poteškoće u ovom području: nepraćenje trendova u skrbi na razini EU-a, nedovoljan broj smještajnih kapaciteta u institucionalnoj skrbi, slabo razvijeni servisi i usluge na razini lokalne zajednice, veliko opterećenje neformalnih njegovatelja bez odgovarajuće podrške, nestandardizacija postojećih usluga i cijena na nacionalnoj razini, nedostupnost mnogih usluga ruralnom stanovništvu itd. (Žganec, Rusac, Laklija, 2008; Puljiz, 2016; Dobrotić, 2016; Bađun, 2017; Štambuk, Rusac, Skokandić, 2019).

U teorijskom smislu udomiteljstvo se može promatrati višedimenzionalno: kroz socijalnu podršku/potporu, socijalne mreže i koncept deinstitucionalizacije. Prizma socijalne podrške /potpore usmjerena je na ispitivanje podrške koju udomitelji pružaju starijim osobama, na kvalitetu dobivene pomoći i stupanj zadovoljstva. Iz perspektive socijalnih mreža udomiteljstvo za osobe starije životne dobi predstavlja formalni odnos između udomitelja i starijih osoba unutar kojeg se starijim osobama pružaju usluge smještaja, a može se promatrati kroz odnose, obrasce i forme između kojih se odvijaju interakcije udomitelj - korisnik. Kroz koncept deinstitucionalizacije udomiteljstvo se promatra $\mathrm{u}$ odnosu na korisnikovu kontrolu nad vlastitim životom, koristi li resurse zajednice u kojoj živi ili je od iste izoliran te radi li se o individualiziranom pristupu pružanja usluga ili ne.

Kao što su pokazala neka istraživanja proces deinstitucionalizacije pridonio je da se usluge pružaju u humanijem obliku pri čemu se pokazalo da je institucionalizacija svagdje u svijetu, uključujući i RH, skupa i da nije najbolje rješenje i u interesu older individual to decide for themselves how they want to live in old age, as well as on a systematic approach to the issues at hand. Therefore, a differentiated range of services should exist, which certainly cannot be confirmed in the case of care for older individuals in Croatia. Researchers dealing with the issue of care for older individuals in Croatia mention various difficulties in this area: failing to keep up with trends in care at the level of the European Union, insufficient number of accommodation facilities in institutional care, poorly developed services at the local community level, heavy workload of informal caregivers without adequate support, non-standardisation of existing services and prices at the national level, and unavailability of many services to the rural population (Žganec, Rusac, Laklija, 2008; Puljiz, 2016; Dobrotić, 2016; Bađun, 2017; Štambuk, Rusac, Skokandić, 2019).

From the theoretical standpoint, foster care can be observed in multi-dimensional terms - through social support, social networks, and the concept of deinstitutionalisation. The social support perspective is focused on investigating the support delivered by foster care providers to older individuals, the quality of assistance received, and the degree of satisfaction. From the perspective of social networks, foster care for older individuals denotes a formal relationship between foster care providers and these individuals where accommodation services are provided to older individuals: it can be studied through relationships, patterns, and forms of the interaction between foster care providers and individuals in need. The deinstitutionalisation concept examines foster care in terms of whether individuals placed in foster families have any control over their lives, whether they use community-based resources or if they are isolated from the community, and whether services are provided through an individualised approach or not.

As demonstrated by certain research studies, the deinstitutionalisation process brought about a more human approach to service provision, while manifesting the high cost of institutionalisation throughout the world, including the Republic of Croatia: this did not represent the best solution, nor was it in the best interest of every individual. Care provision for older individuals hence promotes the 
svake osobe. U skrbi za starije naglasak se stavlja na uspostavu i širenje izvaninstitucionalnih oblika skrbi u kojima će starija osoba, njezina obitelj i uže socijalno okruženje imati aktivnu i važnu ulogu u zadovoljavanju potreba osobe starije životne dobi. Razvoj izvaninstitucijske skrbi omogućuje starijoj osobi da što duže bude uz svoju obitelj i u svojem okruženju i da na taj način odgodi odlazak u instituciju, odnosno u dom za starije. Individualizirana skrb trebala bi se osigurati u smještajnim jedinicama tzv. izvaninstitucijskog karaktera, primjerice $u$ udomiteljskim obiteljima i obiteljskim domovima ili u vlastitom domu starije osobe. Unatoč porastu broja osoba starije životne dobi smještenih u udomiteljske obitelji, izostalo je zanimanje i kritički osvrt znanstvene zajednice za ovaj oblik skrbi. Nadalje bilo bi dobro istražiti različite aspekte udomiteljstva osoba starije životne dobi jer podataka gotovo i da nema, npr. koji se profil osoba smješta u udomiteljsku obitelj, koji su razlozi smještaja te zadovoljstvo smještajem samih korisnika, koja su obilježja i potrebe udomitelja, kakve su primjedbe nadzornih službi i sl. Na taj se način može razumjeti sadašnje stanje i unaprijediti kvaliteta udomiteljske skrbi koja će biti utemeljena na znanstvenim istraživanjima iz kojih mogu proizići smjernice $\mathrm{i}$ preporuke kako za same stručnjake koji rade na poslovima smještaja starijih osoba tako i za udomitelje i korisnike. establishment and the expansion of noninstitutional forms of care in which older individuals, their families, and their immediate social environment will play an active and important role in meeting their needs. The development of noninstitutional care allows older individuals to stay with their families and their community for longer, hence postponing placement in institutions such as retirement homes. Individualised care should be provided in accommodation units of so-called noninstitutional nature, for example in foster families and family homes, or in an older individual's own home.

Despite the fact that in recent years there has been an increase in the number of older individuals placed in foster families in Croatia, there is a lack of interest and critical review by the scientific community concerning this form of care. Furthermore, it would be productive to explore different aspects of foster care for older individuals since there is almost no data regarding this issue: for example, what is the personal profile of people placed in foster families, what are the reasons for placement and users' satisfaction with placement, what are the characteristics and needs of foster care providers, and what are the remarks of supervisory authorities. This could provide insight into the current state of foster care and improve its quality based on scientific research, offering guidelines and recommendations for professionals employed in activities pertaining to the accommodation of older individuals, foster care providers, and the individuals who require care services. 


\section{REFERENCES}

Ajduković, M., Kregar Orešković, K., \& Laklija, M. (2007). Značaj teorije privrženosti za konceptualizaciju javne skrbi za djecu. Ljetopis socijalnog rada, 14(1), 93-118.

Babović, M., Veličković, K., Stefanović, S., Todorović, N., \& Vračević, M. (2018). Socijalna uključenost starijih osoba (65+) u Srbiji. Preuzeto 10. 12. 2020. s: http://humanas.rs/2016/07/26/humanas-publikacije/

Bađun, M. (2017). Financiranje domova za starije i nemoćne osobe u Hrvatskoj. Revija za socijalnu politiku, 24 (1), $19-42$.

Bouillet, D. (2003). Mogućnosti izvaninstitucionalnih oblika skrbi o starijim osobama. Revija za socijalnu politiku, 10(3-4), 321-333.

Bowlby, J. (1988). Secure Base: Clinical Applications of Attachment Theory. London: Routledge.

Braun, K. L., \& Rose, C. L. (1986). The Hawaii geriatric foster care experiment: impact evaluation and cost analysis. Gerontologist, 26(5), 516-524.

Brookes, N., \& Callaghan, L. (2013). What next for Shared Lives? Family-based support as a potential option for older people. Journal of Care Services Management, 7(3), 87-94.

Brookes, N., Palmer, S., \& Callaghan, L. (2016). „I live with other people and not alone”: a survey of the views and experiences of older people using Shared Lives (adult placement). Working with Older People, 20(3), 179-186.

Butković, A. (2005). Udomiteljstvo u Hrvatskoj - sustav i postojeće stanje. U: Brajša Žganec, A., Keresteš, G. i Kuterovac Jagodić, G. (ur.), Udomiteljstvo: skrb o djeci izvan vlastite obitelji (str. 9-14). Zagreb: Udruga za inicijative u socijalnoj politici.

Callaghan, 1., Brookes, N., \& Palmer, S. (2017). Older people receiving family-based support in the community: a survey of quality of life among users of 'Shared Lives' in England. Healt and Social Care, 25(5), 1655-1666.

Cho, E. (2007). A proposed theoretical framework addressing the effects of informal caregivers on health-related outcomes of elderly recipients in home health care. Asian Nursing Research, 1(1), 23-34.

Cohen, S. Underwood, L. G., \& Gottlieb, B. H. (2000). Social support measurement and intervention: A guide for health and social scientists. New York: Oxford University Press.

Ćirić Milovanović, D. (2017). Modeli deinstitucionalizacije i zaštite mentalnog zdravlja u zajednici. Akcija za ljudska prava / Human Rights Action (HRA) Podgorica, Crna Gora.

Despot Lučanin, J. (2003). Iskustvo starenja - doprinos teoriji starenja. Jastrebarsko: Naklada slap.

Despot Lučanin, J. (2008). Zdravstvena psihologija starenja - Prikaz područja i pregled istraživanja u Hrvatskoj. Klinička psihologija, 1, 59-77.

Despot Lučanin, J., Lučanin, D., \& Havelka, M. (2006). Kvaliteta starenja - samoprocjena zdravlja i potrebe za uslugama skrbi. Društvena istraživanja, 15, 801-17.

Dobrotić, I. (2016). Razvoj i poteškoće sustava skrbi za starije osobe u Republici Hrvatskoj. Društvena istraživanja, 25(1), 21-42.

Dobrotić, I., \& Laklija, M. (2012). Obrasci društvenosti i percepcija izvora neformalne socijalne podrške u Hrvatskoj. Društvena istraživanja, 21(1(115)), 39-58.

Freund, A. M., Nikitin, J., \& Ritter, J. O. (2009). Psychological consequences of longevity the increasing importance of self-regulation in old age. Human Development, 52(1), 1-37.

Gašparec, Z. (1991.) Smještaj djece u obitelji hranitelja na području općine Velika Gorica. Socijalna zaštita, 195-200.

Havelka, M. (2000). Potrebe starijih osoba za cjelovitim uslugama skrbi u lokalnoj zajednici. Revija za socijalnu politiku, 7(1), 19-27. 
Hoffman, M. J., \& Romero, H. G. (1994). Foster family care - a nurturing alternative to institutionalization. Caring, 13(10), 36-40

Janković, J., \& Pandža-Ferenčak, M. (1994). Dinamika zadovoljavanja obiteljskih potreba u uvjetima masovne migracije stanovništva u svjetlu triju temeljnih teorija. Revija za socijalnu politiku, 1(1), 53-65.

Jedvaj, S., Štambuk, A., \& Rusac, S. (2014) Demografsko starenje stanovništva i skrb za starije osobe u Hrvatskoj. Socijalne teme: časopis za pitanja socijalnog rada i srodnih znanosti, 1, 135-154.

Kamenov, Ž. (2006). Značaj privrženosti u odrasloj dobi: ima li razloga za pesimizam ili optimizam? XV Dani psihologije. Zadar, str. 9.

Kane, R. L., \& Kane, R. A. (1980). Alternatives to institutional care of the elderly: beyond the dichotomy. Gerontologist, 20(1), 249-259.

Karantzas, G. C., \& Simpson, J. A. (2015). Attachment and aged care. In J.A. Simpson \& W.S. Rholes, (Eds.), Attachment theory and research: New directions and emerging themes (pp. 319-345). New York: Guilford Press.

Katilović, M. (2016). Percepcija socijalne podrške povezane sa sociodemografskim obilježjima kod osoba starije životne dobi. Završni rad. Sveučilište Josipa Jurja Strossmayera. Medicinski fakultet u Osijeku.

Kepeš, N. , Huzejrović, V., \& Kujundžić, H. (2019). Socijalna inkluzija starijih osoba u Bosni i Hercegoviniistraživačka studija. Gračanica: Osmijeh - Društvo za psihosocijalnu pomoć i razvijanje dobrovoljnog rada.

Laklija, M. (2011). Modeli udomiteljstva u Europi. Zagreb: Forum za kvalitetno udomiteljstvo djece.

Laklija, M., \& Barišec, A. (2014). Iskustvo udomiteljstva odraslih osoba s duševnim smetnjama iz perspektive udomitelja. Socijalna psihijatrija, 42(1), 50-61.

Leinonen, E. (2020). Caring in space: the boundaries between public and private spaces in Finnish adult foster care homes. Ageing and Society, First View, 1-18.

Lenko, E. (2016). Deinstitucionalizacija osobnostne oskrbe starostnikov. (Magistarstka naloga). Pravna Fakulteta Univerza v Mariboru, Maribor.

Linn, M. W., Klett, C. J., \& Caffey, E. M. Jr. (1980). Foster home characteristics and psychiatric patient outcome. The wisdom of Gheel confirmed. Archives of General Psychiatry. 37(2), 129-132.

Mali, J. (2012). Uvajanje dezinstitucionalizacije na področju oskrbe starih ljudi. Časopis za kritiko znanosti, 40(250), $86-94$.

Mehrotra, C. M., \& Kosloski, K. (1991). Foster care for older adults: issues and evaluations. Home Health Care Services Quarterly, 12(1), 115-136.

Ministarstvo rada, mirovinskog sustava, obitelji i socijalne politike (2020). Godišnje statističko izvješće o primijenjenim pravima socijalne skrbi, pravnoj zaštiti djece, mladeži, braka, obitelji i osoba lišenih poslovne sposobnosti, te zaštiti tjelesno ili mentalno oštećenih osoba u Republici Hrvatskoj u 2019. godini. Preuzeto 10. 12. 2020. s: https:// mrosp.gov.hr/UserDocsImages/dokumenti/MDOMSP\%20dokumenti/Godisnje\%20statisticko\%20izvjesce\%20 u\%20Republici\%20Hrvatskoj\%20u\%202019\%20godini.pdf

Newman, E. S., \& Sherman, S. R. (1979). Foster-family care for the elderly: surrogate family or mini-institution? The international Journal of Human Development, 10(2), 165-176.

Oktay, J. S., \& Volland, P. J. (1987). Foster home care for the frail elderly as an alternative to nursing home care: an experimental evaluation. American Journal of Public Health. 77(12), 1505-1510.

Petrak, O., Despot Lučanin, J., \& Lučanin, D. (2006). Kvaliteta starenja - neka obilježja starijeg stanovništva Istre i usporedba s drugim područjima Hrvatske. Revija za socijalnu politiku, 13(1), 37-51.

Plan deinstitucionalizacije i transformacije domova socijalne skrbi i drugih pravnih osoba koje obavljaju djelatnost socijalne skrbi u Republici Hrvatskoj 2011.-2016. (NN 36/11) 
Plan deinstitucionalizacije, transformacije te prevencije institucionalizacije 2018. -2020. godina (2018). Preuzeto 1. 12. 2020. s: https://mrosp.gov.hr/UserDocsImages/dokumenti/MDOMSP\%20dokumenti/Plan\%202018-2020.pdf

Plavšić, M. (2012). Usporedba bioloških i socijalnih čimbenika mentalnog zdravlja dviju generacija starijih osoba. (Doktorska disertacija). Filozofski fakultet Sveučilišta u Zagrebu, Zagreb.

Plavšić, M., \& Ambrosi-Randić, N. (2005). U sjeni ladonje: Slika starenja u Istri. Pula: Društvo psihologa Istre.

Podaci o udomiteljstvu odraslih osoba u Poljskoj (2020). Preuzeto 12. 12. 2020 s: https://www.gov.pl/web/gov/szuk aj?query $=$ opieka + zast $\%$ C4\%99pcza

Podaci o udomiteljstvu u Finskoj (2020) Preuzeto 12. 12. 2020. s: https://ec.europa.eu/eip/ageing/repository/olderpeople-family-foster-care-model-city-tampere_en

Puljiz, V. (2016). Starenje stanovništva - izazov socijalne politike. Revija za socijalnu politiku, 23(1), 81-98.

Reinardy, J., \& Kane, R. A. (1999). Choosing an adult foster home or a nursing home: residents' perceptions about decision making and control. Social Work, 44(6), 571-585.

Sabolić, T., \& Vejmelka, L. (2015). Udomiteljstvo djece u Hrvatskoj iz perspektive udomitelja i stručnjaka. Holon, $5(1), 6-42$.

Savanović, N. (2010). Kvalitetno udomiteljstvo djece i odraslih osoba iz perspektive udomitelja na području Baranje. Ljetopis socijalnog rada, 17(2), 223-239.

Selak-Živković, A. (1991). Obitelji hranitelja u gradu Zagrebu. Zagreb: Socijalna zaštita, 33-35, 173-176.

Shunqin, Y. (2015). Review of effects of ,attachment“" of the elderly on physical and mental health of old cronic patients. Studies in Asian Social Science, 2(2), 15-18.

Sladović Franz, B., \& Mujkanović, Đ. (2003). Percepcija socijalne podrške djeci u dječjim domovima i u udomiteljskim obiteljima. Ljetopis socijalnog rada, 10(2), 161-170.

Sokolovska, V., Škorić, M. (2012). Analiza socijalnih mreža II. Filozofski fakultet, Odsek za sociologiju. Novi Sad.

Spitek-Zvonarević, V., \& Takšić, V. (2004). Komparativni pokazatelji kako žive stariji ljudi u Gorskom kotaru, Primorju i Kvarnerskim otocima. Rijeka: Monografija Primorsko goranske županije.

Stefanović-Stanojević, T., Stanojević, S. i Anđelković, V. (2010). Privrženost, agresivnost i potreba za traženjem uzbuđenja u adolescenciji. Ljetopis socijalnog rada, 17, 71-92.

Stiplošek Horvat, B. (2017). Kvaliteta života starijih osoba i korištenje usluga skrbi u zajednici, Završni rad. Sveučilište Sjever.

Strategija razvitka Republike Hrvatske »Hrvatska u 21. stoljeću« - strategija razvitka mirovinskog sustava i sustava socijalne skrbi I. dio Hrvatska: od pasivne prema aktivnoj socijalnoj državi. Narodne novine, 97/2003.

Strateški plan Ministarstva socijalne politike i mladih za razdoblje od 2014.-2016. godine. Preuzeto 1. 12. 2020. s: https://www.yumpu.com/xx/document/view/46949469/strateski-planpdf-ministarstvo-socijalne-politike-i-mladih

Strateški plan razvoja socijalne skrbi u Republici Hrvatskoj. Preuzeto 10. 12. 2020. s: https://vlada.gov.hr/ UserDocsImages//ZPPI/Strategije\%20\%20OGP/socijalna\%20politika//Strategija\%20razvoja\%20sustava\%20 socijalne\%20skrbi\%20u\%20RH\%20\%202011.-2016.[1].pdf

Škara, J. (1999). Ministarstvo rada i socijalne skrbi u socijalnoj skrbi za starije: stanje, problemi i razvojne perspektive. U: M. Pokrajčić, M. Havelka, A. Balaband i V. M. Bužan (ur.): Strategije razvoja skrbi za starije osobe u Republici Hrvatskoj. (str. 7-12). Zagreb: GIPA. 
Štambuk, A., Rusac, S., \& Skokandić, L. (2019). Profil neformalnih njegovatelja starijih osoba u gradu Zagrebu. Revija za socijalnu politiku, 26 (2), 189-205. https://doi.org/10.3935/rsp.v26i2.1579

Štambuk, A., Sučić, M., \& Vrh, S. (2014). Socijalni rad u domu za starije i nemoćne osobe - izazovi i poteškoće. Revija za socijalnu politiku, 2, 185-200.

Šućur, Z. (2003). Razvoj socijalne pomoći i socijalne skrbi u Hrvatskoj nakon Drugoga svjetskog rata, Revija za socijalnu politiku, 10(1), 1-22.

Teodorović, B., \& Miščević, N. (2014). Dodatak zajedničkim europskim smjernicama za prijelaz s institucionalne skrbi na usluge podrške za život u zajednici - Mali priručnik za pružatelje socijalnih usluga. (prijevod) Oxford Policy Management.

The Connexion (2020). Preuzeto 1. 12. 2020. s: https://www.connexionfrance.com/French-news/fostering-systeman-increasingly-popular-alternative-to-residential-care-for-elderly-people-in-France

U.S. Department of Health and Human Services Office of Disability, Aging and Long-Term Care Policy (2010). Understanding Medicaid Home and Community Services. Preuzeto 10. 12. 2020. s: https://aspe.hhs.gov/system/ files/pdf/76201/primer10.pdf

Uchino, B. N. (2004). Social support and physical health: Understanding the health consequences of relationships. New Haven: Yale University Press.

Vručinić, Z. (2012). Socijalna podrška i nezaposlenost. Defendologija, 15, 76-82.

Vuković, O., Vuković, D., \& Cvejić, S. (2013). Uporedno istraživanje lokalnih pružalaca usluga socijalne zaštite u Srbiji: konkurentnost i inovativnost civilnog sektora. Beograd: Trag Fondacija.

Zakon o udomiteljstvu. Narodne novine, 79/07, 115/18

Zakon o izmjenama i dopunama Zakona o udomiteljstvu. Narodne novine, 78/12

Zakon o socijalnoj skrbi. Narodne novine, 157/13, 152/14, 99/15, 52/16, 16/17, 130/17, 98/19, 64/20

Zakon o socijalnoj zaštiti. Narodne novine, 19/69

Žganec, N. (1995). Obitelj - socijalna mreža - socijalni rad. Društvena istraživanja, 4-5, 503-515.

Žganec, N., Rusac, S., \& Laklija, M. (2008). Trendovi u skrbi za osobe starije životne dobi u Republici Hrvatskoj i u zemljama Europske Unije. Revija za socijalnu politiku, 15(2), 171-188.

Žižak, A. (2008). Udomiteljstvo djece u Hrvatskoj. Analiza stanja i preporuke. UNICEF. 